\title{
Article \\ Molecular Mechanisms of Antiproliferative and Apoptosis Activity by 1,5-Bis(4-Hydroxy-3-Methoxyphenyl) 1,4-Pentadiene-3-one (MS13) on Human Non-Small Cell Lung Cancer Cells
}

\author{
Wan Nur Baitty Wan Mohd Tajuddin ${ }^{1}$, Faridah Abas ${ }^{2,3} \mathbb{D}^{\text {, }}$, Iekhsan Othman 1,4 (D) and Rakesh Naidu 1,4,*(D) \\ 1 Jeffrey Cheah School of Medicine and Health Sciences, Monash University Malaysia, Jalan Lagoon Selatan, \\ Bandar Sunway 47500, Selangor Darul Ehsan, Malaysia; wan.wanmohdtajuddin@monash.edu (W.N.B.W.M.T.); \\ iekhsan.othman@monash.edu (I.O.) \\ 2 Laboratory of Natural Products, Faculty of Science, Universiti Putra Malaysia, UPM, Serdang 43400, Malaysia; \\ faridah_abas@upm.edu.my \\ 3 Department of Food Science, Faculty of Food Science and Technology, Universiti Putra Malaysia, UPM, \\ Serdang 43400, Malaysia \\ 4 Global Asia in the 21s Century Platform, Monash University Malaysia, Jalan Lagoon Selatan, \\ Bandar Sunway 47500, Selangor Darul Ehsan, Malaysia \\ * Correspondence: rakesh.naidu@monash.edu; Tel.: +60-3-5514-63-45
}

Citation: Wan Mohd Tajuddin, W.N.B.; Abas, F.; Othman, I.; Naidu, R. Molecular Mechanisms of Antiproliferative and Apoptosis Activity by 1,5-Bis(4-Hydroxy-3Methoxyphenyl)1,4-Pentadiene-3-one (MS13) on Human Non-Small Cell Lung Cancer Cells. Int. J. Mol. Sci. 2021, 22, 7424. https://doi.org/ $10.3390 /$ ijms 22147424

Academic Editor:

Melpo Christofidou-Solomidou

Received: 14 June 2021

Accepted: 4 July 2021

Published: 10 July 2021

Publisher's Note: MDPI stays neutral with regard to jurisdictional claims in published maps and institutional affiliations.

Copyright: (c) 2021 by the authors. Licensee MDPI, Basel, Switzerland. This article is an open access article distributed under the terms and conditions of the Creative Commons Attribution (CC BY) license (https:/ / creativecommons.org/licenses/by/ $4.0 /)$.

\begin{abstract}
Diarylpentanoid (DAP), an analog that was structurally modified from a naturally occurring curcumin, has shown to enhance anticancer efficacy compared to its parent compound in various cancers. This study aims to determine the cytotoxicity, antiproliferative, and apoptotic activity of diarylpentanoid MS13 on two subtypes of non-small cell lung cancer (NSCLC) cells: squamous cell carcinoma (NCI-H520) and adenocarcinoma (NCI-H23). Gene expression analysis was performed using Nanostring PanCancer Pathways Panel to determine significant signaling pathways and targeted genes in these treated cells. Cytotoxicity screening revealed that MS13 exhibited greater inhibitory effect in NCI-H520 and NCI-H23 cells compared to curcumin. MS13 induced anti-proliferative activity in both cells in a dose- and time-dependent manner. Morphological analysis revealed that a significant number of MS13-treated cells exhibited apoptosis. A significant increase in caspase- 3 activity and decrease in Bcl-2 protein concentration was noted in both MS13-treated cells in a time- and dose-dependent manner. A total of 77 and 47 differential expressed genes (DEGs) were regulated in MS13 treated-NCI-H520 and NCI-H23 cells, respectively. Among the DEGs, 22 were mutually expressed in both NCI-H520 and NCI-H23 cells in response to MS13 treatment. The top DEGs modulated by MS13 in NCI-H520-DUSP4, CDKN1A, GADD45G, NGFR, and EPHA2-and NCI-H23 cells-HGF, MET, COL5A2, MCM7, and GNG4-were highly associated with PI3K, cell cycle-apoptosis, and MAPK signaling pathways. In conclusion, MS13 may induce antiproliferation and apoptosis activity in squamous cell carcinoma and adenocarcinoma of NSCLC cells by modulating DEGs associated with PI3K-AKT, cell cycle-apoptosis, and MAPK pathways. Therefore, our present findings could provide an insight into the anticancer activity of MS13 and merits further investigation as a potential anticancer agent for NSCLC cancer therapy.
\end{abstract}

Keywords: lung cancer; curcumin analogue; diarylpentanoid; cytotoxicity; anti-proliferation; apoptosis; gene expression

\section{Introduction}

Lung cancer is the most commonly diagnosed cancer worldwide with a high mortality rate [1]. Lung cancer is grouped into two main types: non-small cell lung cancer (NSCLC) and small cell lung cancer (SCLC). NSCLC is the most common type of lung cancer, representing approximately $80 \%$ of all lung cancer cases compared to SCLC (20\%). NSCLC 
is further classified into three subtypes: squamous cell carcinoma ( $40 \%)$, adenocarcinoma $(30 \%)$ and large cell carcinoma (10\%) [2]. The main risk factor of both NSCLC and SCLC is tobacco smoking, with $80-90 \%$ of lung cancer patients have smoking history [3]. To date, the standard treatments for both NSCLC and SCLC patients are surgery, chemotherapy, radiation therapy, or a combination of these treatments [4]. Despite various advanced diagnostic and therapeutic approaches of lung cancer, the overall 5-year survival rate remains poor: $10 \%$ to $20 \%$ for all stages combined [1]. Additionally, several side effects and toxicities of chemotherapy and radiation therapy have been reported in lung cancer patients $[4,5]$. Thus, there is a need to identify more effective and non-toxic therapeutic drugs for the treatment of lung cancer patients.

Phytocompounds represent one of the promising therapeutic agents that has been studied extensively in preventing and treating various human diseases with reduced side effects [6]. Curcumin, the main component extracted from Curcuma longa, has been well documented to possess numerous therapeutic properties including anti-inflammatory [7], antioxidative [8], antimicrobial [9], and anticancer [10]. Previous in vitro and in vivo studies revealed that curcumin acts as a potential candidate of chemopreventive agent and a novel adjuvant for multiple cancer types including lung cancer [11]. Curcumin has been indicated to exhibit its anticancer effect in lung cancer cells through various mechanisms including inhibition of cell proliferation, metastasis and invasion, induction of apoptosis, and regulation of microRNAs expression. These mechanisms were governed by multiple molecular targets and signaling pathways such as STAT3, EGFR, FOXO3a, TGF- $\beta$, eIF2 $\alpha$, COX-2, Bcl-2, PI3KAkt/mTOR, ROS, Fas/FasL, Cdc42, E-cadherin, MMPs, and adiponectin [12]. However, despite its broad therapeutic properties as an anticancer agent, pharmacokinetic profile studies have highlighted the bioavailability limitation of curcumin as it has poor absorption and rapid metabolism [13]. Therefore, numerous chemically modified compounds of curcumin have been synthesized to overcome the curcumin limitations while retaining its efficacy as well as safety profile.

Diarylpentanoids (DAPs) are curcumin analogs with a 5-carbon chain between their aryl rings that have been demonstrated to have more significant anti-tumorigenic effect compared to curcumin. Multiple experimental studies showed that DAPs exhibited anticancer therapeutic properties through the growth inhibition and induction of apoptosis in human cancer cells. Among the DAPs, GO-Y030, FLLL-11, FLLL-12, HO-3867, EF24, and EF31 demonstrated greater growth inhibitory effect in various human cancer cells compared to its parent compound, curcumin [14]. These compounds have been shown to exert its growth inhibitory effect by mediating a wide range of signaling pathways and molecular targets including NF-KB, PI3K/PTEN/Akt/mTOR, MAPK/ERK pathway, VEGF signaling, cell cycle arrest, and apoptotic pathways [15-17].

MS13, also known as 1,5-bis(4-hydroxy-3-methoxyphenyl)1,4-pentadiene-3-one, is a mono-ketone derivative that holds $\alpha$ - and $\beta$-unsaturated ketone moiety [18]. This compound has been indicated to exhibit greater cytotoxic effect with lower $\mathrm{EC}_{50}$ values towards prostate [19], cervical [20], colon [21], glioblastoma, and neuroblastoma [22] cancer cells. Additionally, MS13 demonstrated its anticancer activity through induction of apoptosis in colon [21], glioblastoma, and neuroblastoma [22] cancer cells. To the best of our knowledge, this is the first study to evaluate anticancer properties of 1,5-bis(4-hydroxy-3methoxyphenyl)1,4-pentadiene-3-one against NSCLC cells and its underlying molecular mechanisms. Therefore, in the present study, we investigated the cytotoxicity, antiproliferative, and apoptotic activity of MS13 in NSCLC squamous cell carcinoma (NCI-H520) and adenocarcinoma (NCI-H23). Furthermore, we investigated the underlying molecular mechanisms in MS13-treated human NSCLC cells by identifying differentially expressed genes (DEGs) and associated signaling pathways using the Nanostring PanCancer Pathways Panel. In this study, we highlighted the signaling pathways that were highly associated with NSCLC including PI3K-AKT, cell cycle-apoptosis, and MAPK pathways. 


\section{Results}

\subsection{Cytotoxic Effects of MS13 on NCI-H520 and NCI-H23 Cell Lines}

The dose-dependent cytotoxic effect of MS13 and curcumin on human lung cancer cell lines NCI-H520 and NCI-H23 was determined by evaluating the cell viability using MTT assay at $72 \mathrm{~h}$ as depicted in Figure 1. MS13 showed a significant inhibition of growth on NCI-H520 with a significant decrease in cell viability to $79 \%$ at $3.1 \mu \mathrm{M}$ and gradually to $23 \%$ at $6.3 \mu \mathrm{M}$ and less than $5 \%$ at $12.5 \mu \mathrm{M}$ onwards. Similarly, MS13 demonstrated a significant cell inhibitory effect on NCI-H23 at $3.1 \mu \mathrm{M}$ by decreasing the cell viability to $60 \%$ followed by less than $10 \%$ at $6.3 \mu \mathrm{M}$ onwards compared to the control. On the other hand, curcumin demonstrated significant decrease in cell viability on NCI-H520 and NCI-H23 cells at $25 \mu \mathrm{M}(50 \%)$ and $12.5 \mu \mathrm{M}(85 \%)$, respectively.

A)

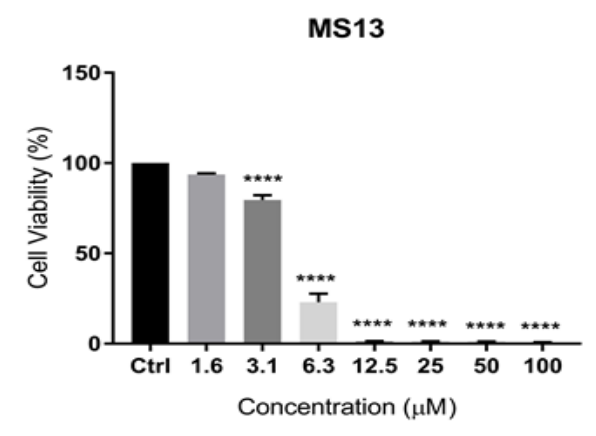

B)

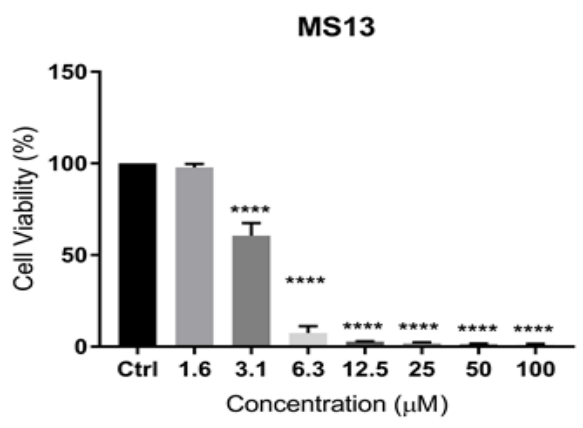

C)

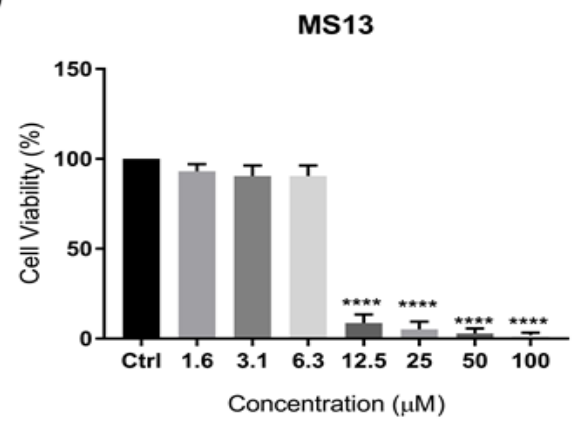

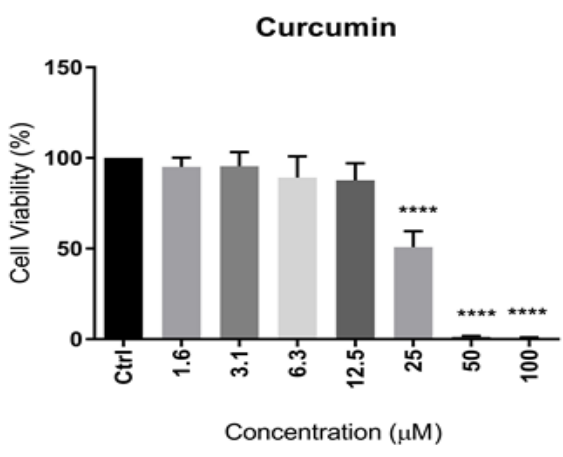

Curcumin

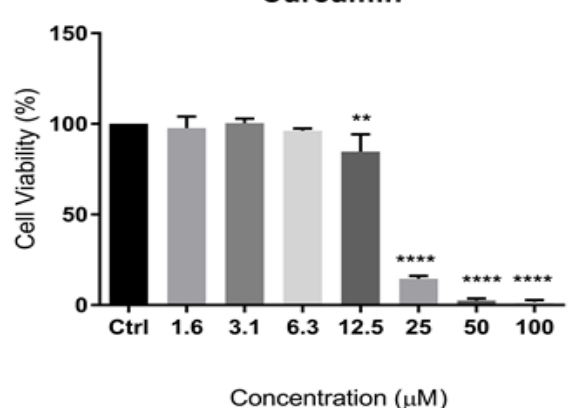

Curcumin

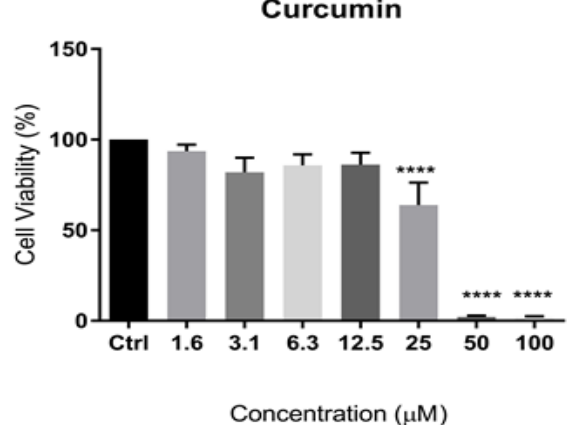

Figure 1. The cytotoxic effects of MS13 and curcumin at different concentrations on (A) NCI-H520, (B) NCI-H23, and (C) MRC9 cell lines compared to untreated sample (Ctrl) at $72 \mathrm{~h}$ of incubation. The experiments were performed in triplicates, and results were compared between three independent experiments. The data are presented as means of percentage of cell viability and comparison between data sets were statistically analyzed using ANOVA. Asterisks indicate statistically significant differences between the means of the values obtained with treated versus untreated cells $\left({ }^{* *} p<0.01\right.$, and $\left.{ }^{* * * *} p<0.0001\right)$. 
Table 1 showed the $\mathrm{EC}_{50}$ values of MS13 and curcumin on NCI-H520 and NCI-H23 cells obtained from cytotoxicity data. MS13 demonstrated lower EC 50 value in NCI-H23 cells $(3.7 \pm 0.4 \mu \mathrm{M})$ compared to NCI-H520 cells $(4.7 \pm 0.1 \mu \mathrm{M})$. These results indicate that MS13 possess greater inhibitory effect against NCI-H23 in comparison with NCI-H520. Curcumin showed higher EC $_{50}$ value in both NCI-H520 (25.2 $\left.\pm 1.7 \mu \mathrm{M}\right)$ and NCI-H23 $(18.5 \pm 0.7 \mu \mathrm{M})$ compared to MS13. The cytotoxic effects of MS13 as well as curcumin were further evaluated on the non-cancerous lung fibroblast cell line MRC9 (Figure 2). The results demonstrated that the $\mathrm{EC}_{50}$ values of both compounds were higher in MRC9 compared to cancer cell lines, indicating higher dose of MS13 and curcumin was required to decrease MRC9 cell viability by 50\%. MS13 and curcumin showed SX values above 100 in NCI-H520 and NCI-H23 cells indicating that the cytotoxic effect of both the compounds is greater towards cancer cells compared to normal cells (Table 1). MS13 exhibited comparably higher SX values in both NCI-H520 and NCI-H23 cells compared to curcumin.

Table 1. EC $_{50}$ values of curcumin and MS13 on NCI-H520, NCI-H23, and MRC9 cells and their selective indices.

\begin{tabular}{cccccc}
\hline \multirow{2}{*}{ Compounds } & \multicolumn{3}{c}{ EC $_{\text {50 Values }}(\mu \mathrm{M})$} & \multicolumn{2}{c}{ Selective Index (SX) } \\
\cline { 2 - 6 } & NCI-H520 & NCI-H23 & MRC9 & NCI-H520 & NCI-H23 \\
\hline MS13 & $4.7 \pm 0.1$ & $3.7 \pm 0.4$ & $8.6 \pm 0.6$ & 181.4 & 232.4 \\
Curcumin & $25.19 \pm 1.7$ & $18.5 \pm 0.7$ & $27.4 \pm 1.7$ & 108.8 & 148.2 \\
\hline
\end{tabular}

Results are shown as mean \pm standard deviation (S.D) from three independent experiments.

A)

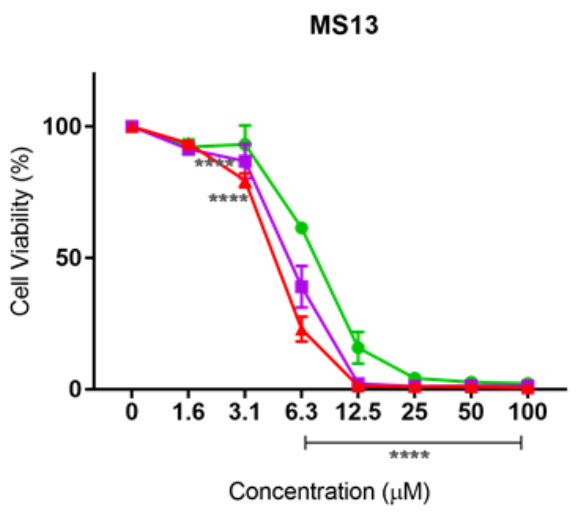

B)

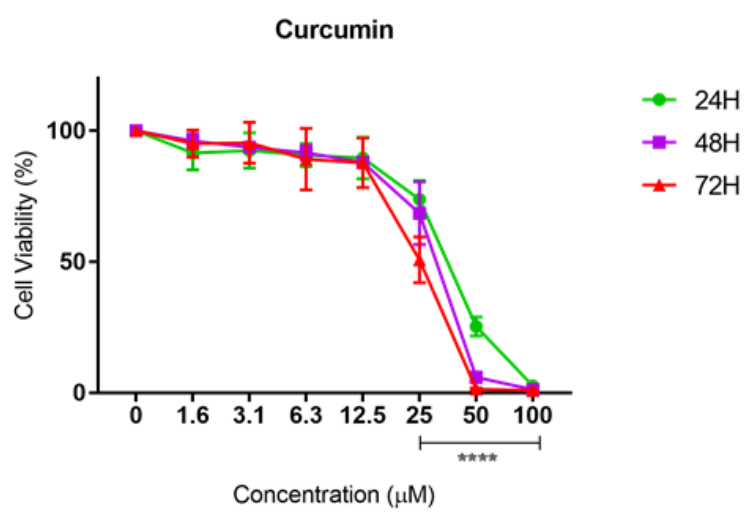

C)

DMSO only (Vehicle)

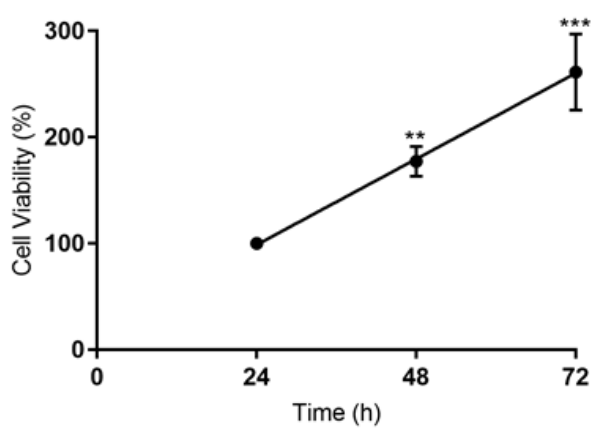

Figure 2. The antiproliferative effects of (A) MS13 and (B) curcumin on NCI-H520 cell line at 24, 48, and 72 h. The experiments were performed in triplicate and results were compared between three independent experiments. Results are presented as means of percentage of cell viability and comparison between data sets were statistically analyzed using ANOVA. Vehicle-treated controls of DMSO (C) were included to assess cell growth in untreated NCI-H520 cells over time. Asterisks indicate statistically significant differences between the means of the values obtained with treated versus untreated cells ${ }^{* *} p<0.01,{ }^{* * *} p<0.001$ and $\left.{ }^{* * *} p<0.0001\right)$. 


\subsection{Antiproliferative Effect of MS13 on NCI-H520 and NCI-H23 Cell Lines}

The antiproliferative effect of MS13 and curcumin against NCI-H520 and NCI-H23 cells was assessed by measuring the viability of treated cells at 24,48 , and $72 \mathrm{~h}$. In addition, the cell viability of vehicle-treated (DMSO only) cells was measured to assess the cell proliferation in the absence of MS13 treatment. A significant increase of cell viability was observed from 24 to $72 \mathrm{~h}$ in vehicle-treated cells, suggesting that the cell proliferation increases as a function of time (Figures $2 \mathrm{C}$ and $3 \mathrm{C}$ ). However, the proliferation rate of the treated cells was significantly reduced in a dose- and time-dependent manner.

A)

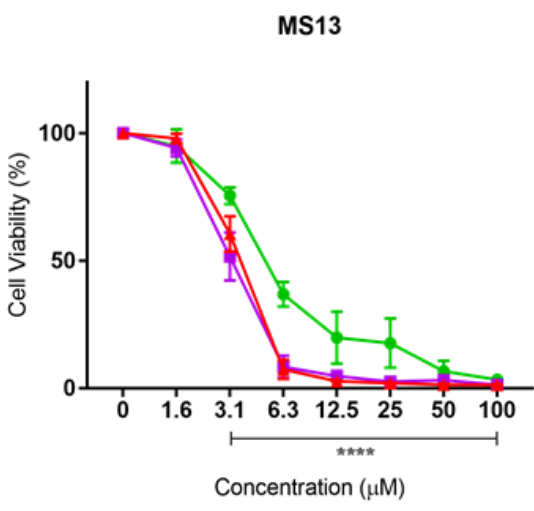

C)
B)

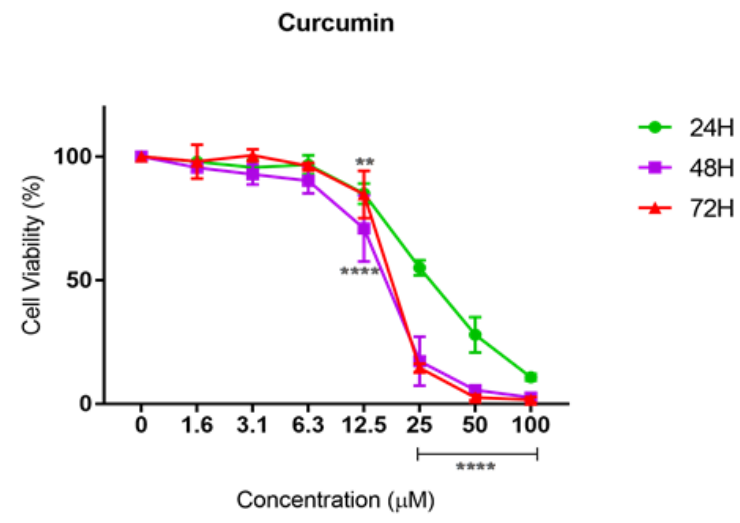

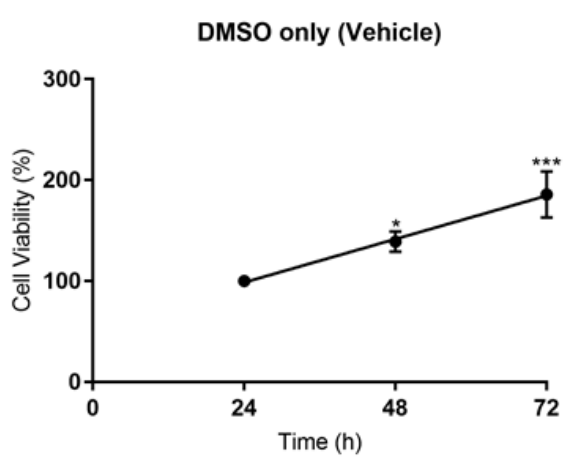

Figure 3. The antiproliferative effects of (A) MS13 and (B) curcumin on NCI-H23 cell line at 24, 48, and $72 \mathrm{~h}$. The experiments were performed in triplicate and results were compared between three independent experiments. Results are presented as means of percentage of cell viability and comparison between data sets were statistically analyzed using ANOVA. Vehicle-treated controls of DMSO (C) were included to assess cell growth in untreated NCI-H520 cells over time. Asterisks indicate statistically significant differences between the means of the values obtained with treated versus untreated cells ${ }^{*} p<0.05,{ }^{* *} p<0.01,{ }^{* * *} p<0.001$ and $\left.{ }^{* * * *} p<0.0001\right)$.

As depicted in Figure 2A, the MS13 treatment against NCI-H520 cells showed a significant decline in cell viability to $61 \%$ at $6.3 \mu \mathrm{M}$ upon $24 \mathrm{~h}$ incubation. At a dosage of $3.1 \mu \mathrm{M}$, a significant decrease in cell viability to $86 \%$ and $78 \%$ at $48 \mathrm{~h}$ and $72 \mathrm{~h}$, respectively, was noted. Cell viability of less than $50 \%$ was observed upon MS13 treatment at $6.3 \mu \mathrm{M}$ for 48 and $72 \mathrm{~h}$ as well as $12.5 \mu \mathrm{M}$ for $24 \mathrm{~h}$. The cell viability showed a significant decrease at $6.3 \mu \mathrm{M}$ following incubation for $48 \mathrm{~h}(40 \%)$ and $72 \mathrm{~h}(30 \%)$. Cell viability of less than $15 \%$ was observed following $12.5 \mu \mathrm{M}$ of MS13 treatment at all time points. Meanwhile, NCI-H520 cell treated with curcumin at $25 \mu \mathrm{M}$ demonstrated a significant reduction in cell viability to $74 \%, 69 \%$, and $51 \%$ at 24,48 , and $72 \mathrm{~h}$, respectively (Figure $2 \mathrm{~B}$ ). At a dosage of $50 \mu \mathrm{M}$, curcumin significantly decreased the cell viability of NCI-H520 cells to less than $50 \%$ at all time points. 
As for NCI-H23 cells, the MS13 treatment at $3.1 \mu \mathrm{M}$ significantly reduced cell viability to $75 \%, 52 \%$, and $60 \%$ at $24 \mathrm{~h}, 48 \mathrm{~h}$, and $72 \mathrm{~h}$, respectively (Figure $3 \mathrm{~A}$ ). Upon MS13 treatment at $6.3 \mu \mathrm{M}$, cell viability less than $50 \%$ was observed at all time points. At a dosage of $12.5 \mu \mathrm{M}$ onwards, MS13 treatment significantly reduced the cell viability to less than $20 \%$ at $24 \mathrm{~h}$ and $3-5 \%$ at $48 \mathrm{~h}$ and $72 \mathrm{~h}$. On the other hand, curcumin treatment at $25 \mu \mathrm{M}$ onwards against NCI-H23 cells exhibited a significant decline to $55 \%$ after $24 \mathrm{~h}$ of incubation (Figure 3B). At a dosage of $12.5 \mu \mathrm{M}$ of curcumin treatment, cell viability was significantly reduced to $70 \%$ and $84 \%$ at $48 \mathrm{~h}$ and $72 \mathrm{~h}$, respectively. Cell viability less than $50 \%$ was observed at $25 \mu \mathrm{M}(48 \mathrm{~h}$ and $72 \mathrm{~h})$ and $50 \mu \mathrm{M}(24 \mathrm{~h})$ of MS13 treatment. In addition, MS13 and curcumin significantly showed greater inhibitory effect at $48 \mathrm{~h}$ and $72 \mathrm{~h}$ compared to $24 \mathrm{~h}$ at all concentrations. Overall, the results indicated that treatment with the MS13 demonstrated greater antiproliferative activity on NCI-H520 and NCI-H23 cells compared to curcumin in time- and dose-dependent manner.

\subsection{Morphological Observation of Apoptotic Cells by Acridine Orange}

\subsubsection{Propidium Iodide (AO-PI) Double Staining}

The apoptotic activity of MS13 on NCI-H520 and NCI-H23 cells was assessed through morphological observation by acridine orange $(\mathrm{AO})$ and propidium iodide (PI) double staining method using fluorescent microscope.

$\mathrm{AO}$ is an intercalating dye that can permeate viable and apoptotic cells, staining nuclear DNA in an intact cell membrane to generate green fluorescence. On the other hand, propidium iodide only penetrates dead cells with poor membrane integrity, staining all dead nucleated cells to generate red fluorescence. Therefore, every viable and apoptotic cell would exhibit different colors and characteristics upon AO/PI double staining [23,24]. Viable cells with intact membrane would exhibit uniform green nuclei, whereas early apoptotic cells would generate bright green nuclei with the additional characteristic of condensed or fragmented chromatin and membrane blebbing. Late apoptotic cells would exhibit yellow-orange to bright red fluorescence due to increased permeability of PI and condensed chromatin feature. As for necrotic cells, they would exhibit orange or red uniform nuclei since the cells would be fully permeable to AO and PI.

The morphological features of MS13-treated NCI-H520 and NCI-H23 cells morphological features are shown in Figure 4. Both treated cell lines showed a significant decrease in the appearance of viable cells and a notable increase in apoptotic cells as the treatment doses and time increase. In comparison with untreated cells (control), the morphological observation in the cell nuclei of treated cells showed various morphological alterations. In NCI-H520 cells (Figure 4A), treatment with 5 and $10 \mu \mathrm{M}$ of MS13 showed an increased number of early apoptotic cells, which was indicated by bright green in appearance (red arrow). At $48 \mathrm{~h}$, the treated cells for both doses demonstrated an increased number of early (red arrow) as well as late apoptotic cells (yellow arrow) compared to the treated cells at $24 \mathrm{~h}$. However, at $72 \mathrm{~h}$, the cells treated with 5 and $10 \mu \mathrm{M}$ displayed a mixed population of late apoptotic and necrotic cells and an increased in number of yellow-orange to bright red stained cells compared to $48 \mathrm{~h}$ of treatment. Regarding NCI-H23 cells (Figure 4B), MS13 treatment at 4 and $8 \mu \mathrm{M}$ of MS13 for $24 \mathrm{~h}$ displayed higher intensity of bright green fluorescent cells (red arrow) compared to the control, indicating a great number of early apoptotic cells present. However, at $48 \mathrm{~h}$ for both doses, a mixed population of cells bright green to yellow and small number of yellow-orange stained cells, indicating the presence of early and late apoptotic cells (red and yellow arrow) was observed. Upon 72 h of MS13 treatment at $8 \mu \mathrm{M}, \mathrm{NCI}-\mathrm{H} 23$ cells displayed an increase of cells stained yellow-orange with condensed chromatin feature indicating the presence of late apoptotic cells as well as orange to red uniform nuclei indicating necrotic cells. 
A)

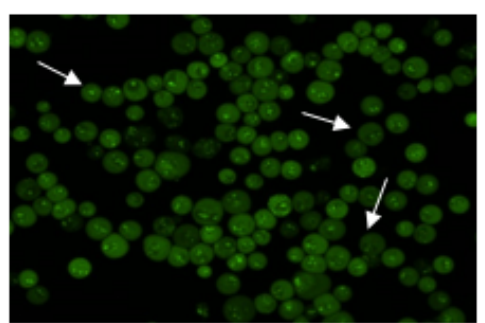

$48 \mathrm{~h}$

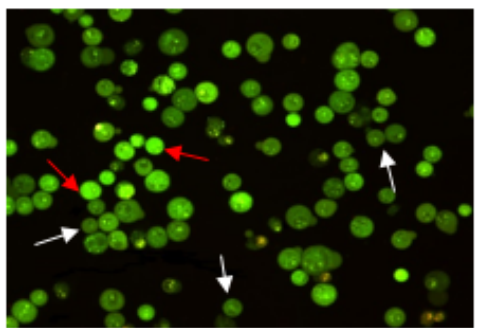

$72 \mathrm{~h}$

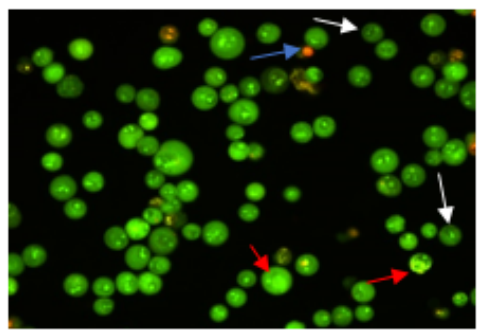

B)

Control

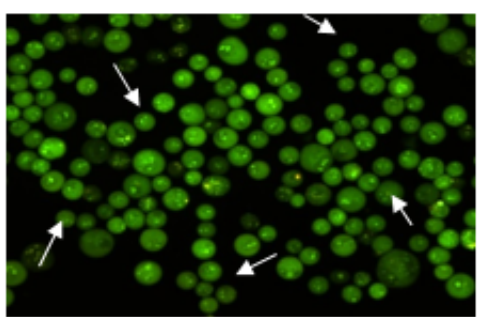

$48 \mathrm{~h}$
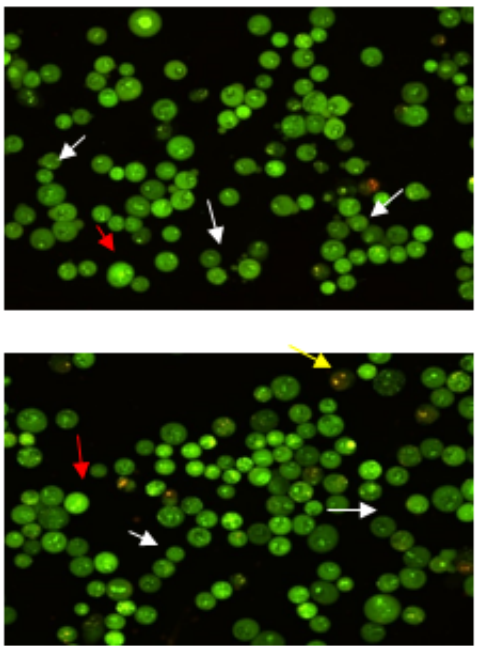

$5 \mu \mathrm{M}$
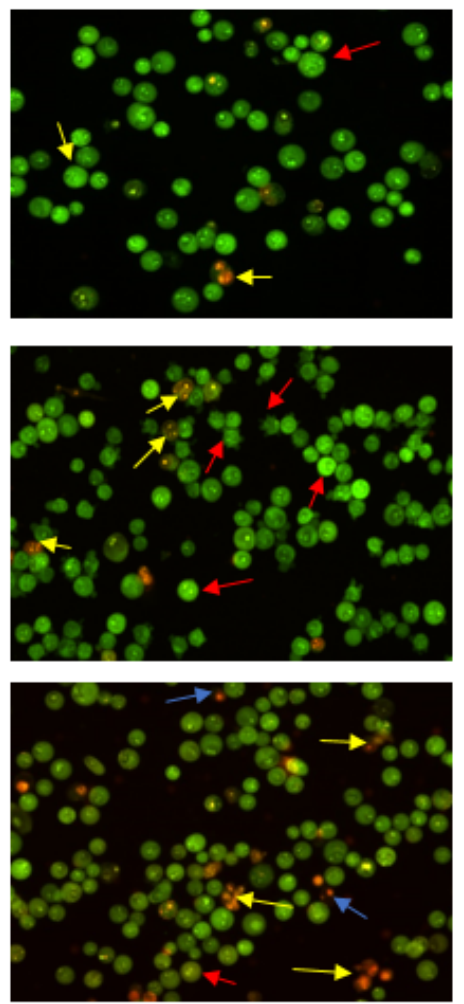

$4 \mu \mathrm{M}$
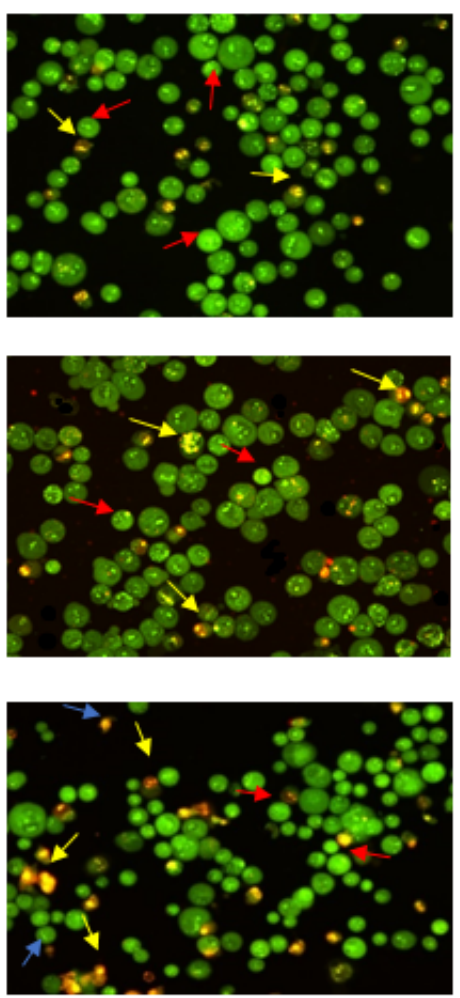

$10 \mu \mathrm{M}$
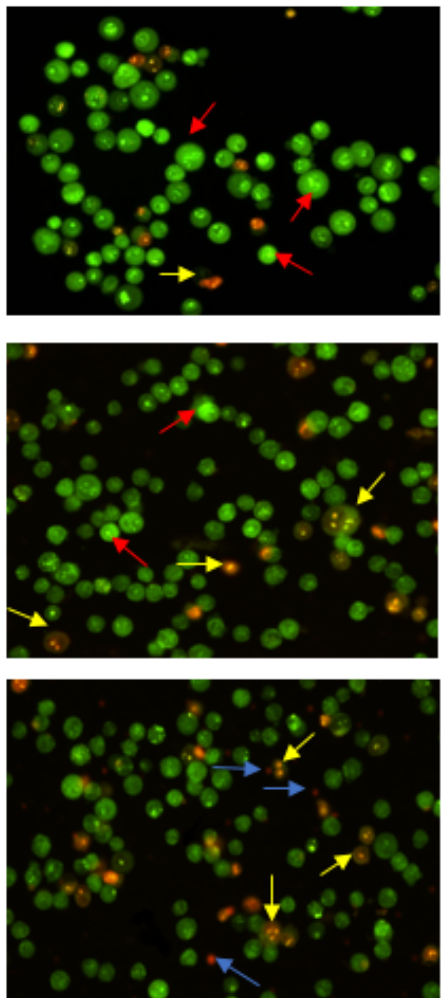

$8 \mu \mathrm{M}$
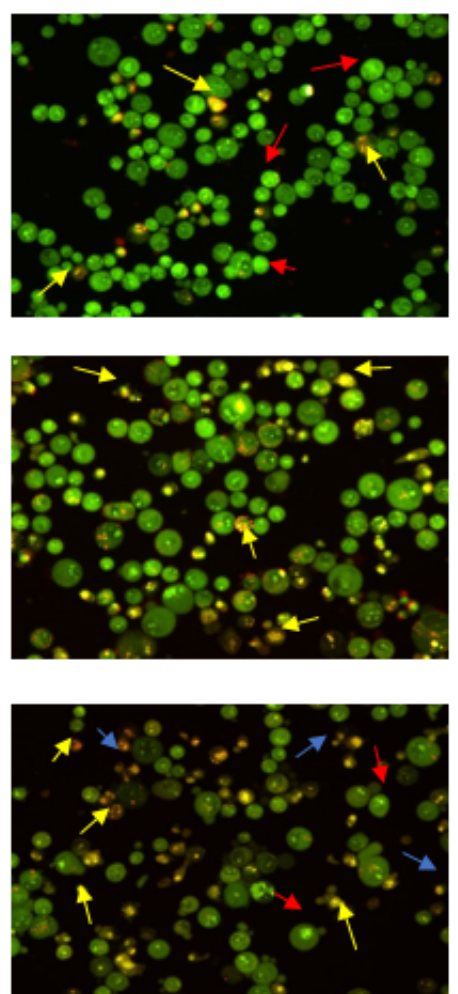

Figure 4. Detection by fluorescent microscope of acridine orange/propidium iodide double stained (A) NCI-H520 and (B) NCI-H23 cells treated with MS13 for 24, 48, and $72 \mathrm{~h}$. Untreated viable cells are uniformly pale-green (white arrow). Early apoptotic cells showed characteristic loss of membrane integrity, membrane blebbing, and chromatin condensation, stained bright-green (red arrow). Late apoptotic cells stained yellow-orange to bright red, with a condensed or fragmented chromatin (yellow arrow). Necrotic cells showed orange or red uniform nuclei (blue arrow). Magnification is at $100 \times$. 


\subsubsection{Quantification of Apoptotic and Necrotic Cells}

The percentages of apoptotic and necrotic cells were also determined. For the purpose of analysis, early and late apoptosis were combined to indicate apoptotic activity. As observed in Figure 5, the percentage of viable cells decreased upon exposure to longer incubation times in both cell lines. Between the time points, there was an increase of apoptosis in all concentrations compared to the untreated samples (control). The results showed a comparatively increase percentage of cells undergoing apoptosis at 24,48 , as well as $72 \mathrm{~h}$ as treatment doses increased in both cell lines.

(A)

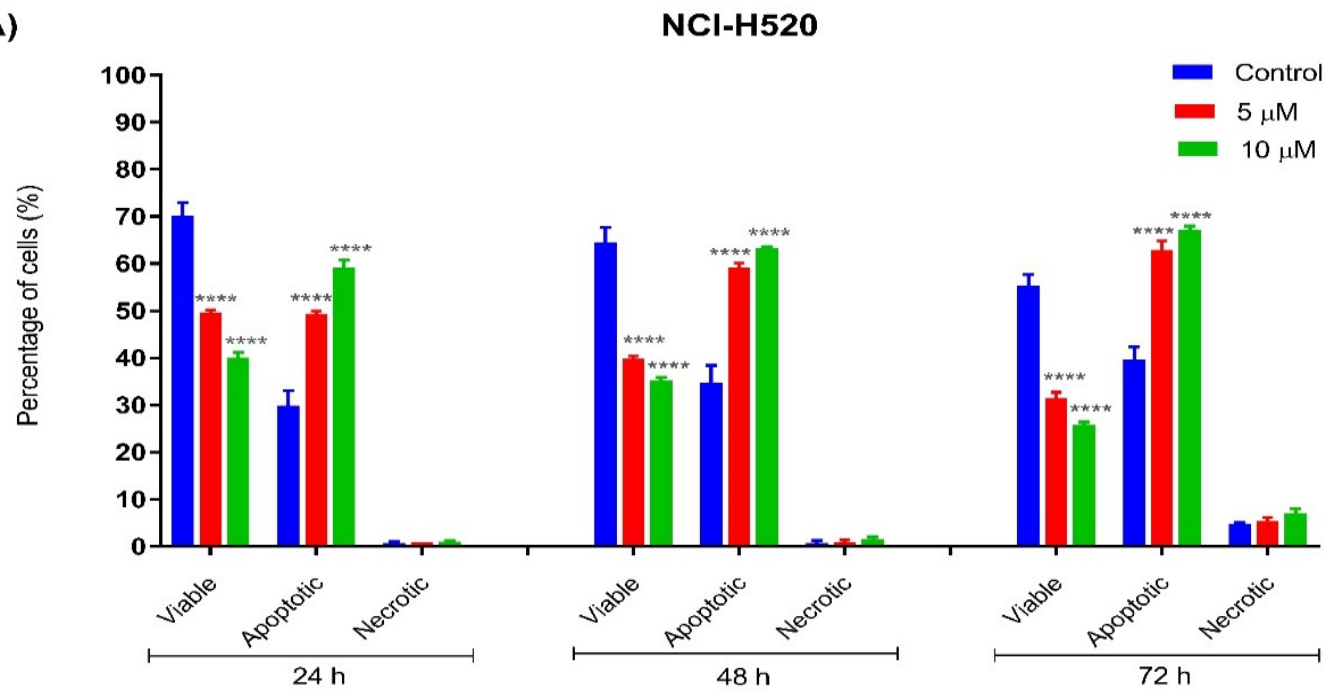

(B)

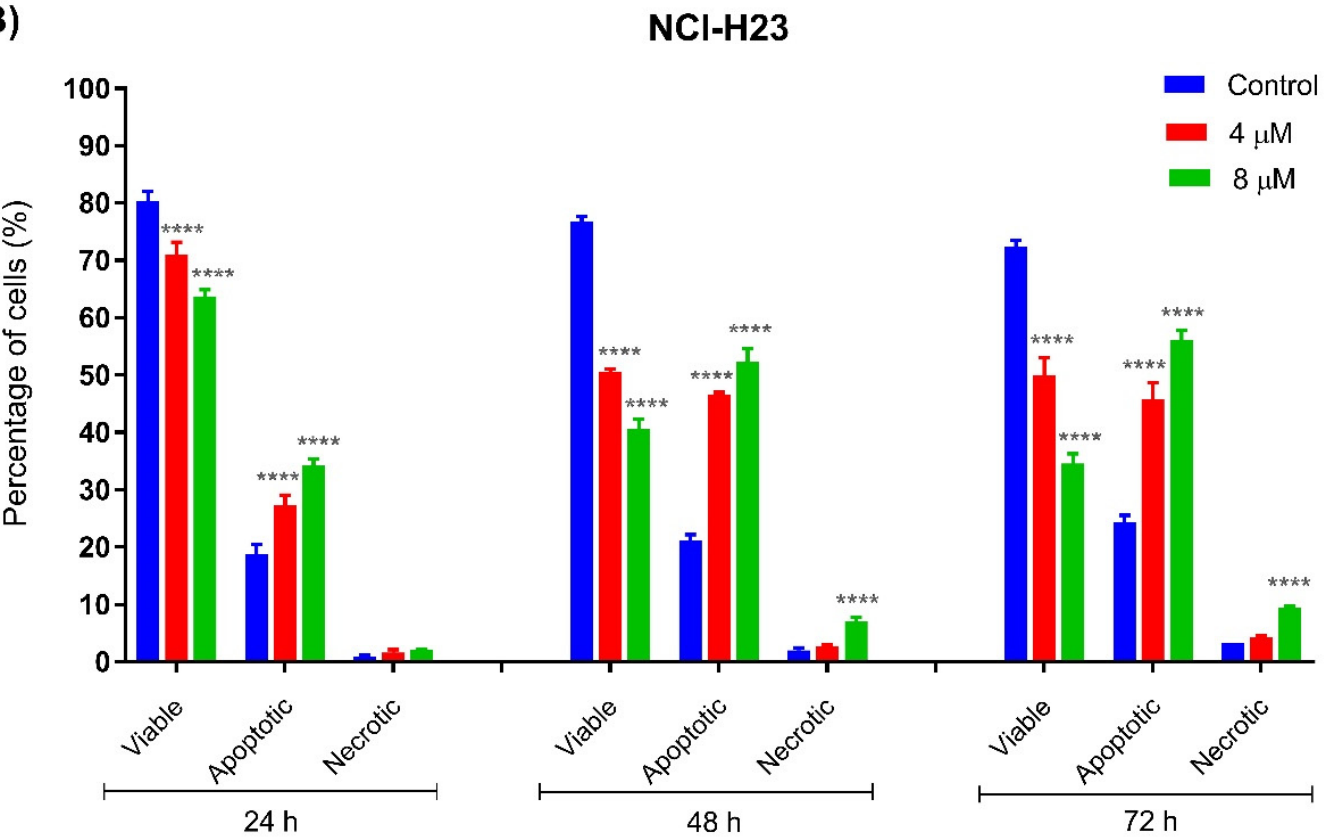

Figure 5. Percentage of cell population in (A) NCI-H520 and (B) NCI-H23 cells treated with MS13 for 24, 48, and 72 h. Treated and non-treated cells were double stained with AO/PI and a minimum of 200 cells were counted per sample and the percentage of cells from each population (viable, apoptotic, and necrotic) was calculated. Samples were run in triplicates and comparable results were obtained from three independent experiments. Comparison between data sets was performed using ANOVA. ${ }^{* * *} p<0.0001$ indicates statistically significant differences between the means of values obtained with treated vs. control. 
As shown in Figure 5A, viable cells of untreated NCI-H520 cells with approximately more than $60 \%$ were noted at all time points $(24,48$, and $72 \mathrm{~h}$ ) compared to MS13-treated cells $(5$ and $10 \mu \mathrm{M})$. A significant decrease of viable cells in MS13-treated cells compared to untreated cells was noted at all time points by approximately $20-30 \%$ in a dose-dependent manner. The NCI-H520 cells treated with MS13 demonstrated a significant increase in apoptotic cells at 24,48 , and $72 \mathrm{~h}$ to approximately $50-60 \%, 60-65 \%$, and $65-75 \%$, respectively, in a dose-dependent manner. Higher apoptosis activity of NCI-H520 cells treated with MS13 was observed at incubation time of 48 and $72 \mathrm{~h}$ compared to $24 \mathrm{~h}$. Although the apoptosis activity was relatively high at 48 and $72 \mathrm{~h}$, the necrotic cells appeared to be low with less than $10 \%$ in the treated cells at these two points. Interestingly, no significant difference of necrotic cells was observed in NCI-H520 treated cells compared to untreated cells at both doses and time points.

As for NCI-H23 cells, more than approximately $70 \%$ of viable cells of untreated cells were noted at all time points (Figure 5B). The MS13 treatment with doses of $4 \mu \mathrm{M}$ and $8 \mu \mathrm{M}$ in NCI-H23 significantly reduced the viable cells to approximately $60-70 \%$ compared to untreated cells $(80 \%)$ at $24 \mathrm{~h}$ in a dose-dependent manner. The percentage of MS13-treated viable cells at both doses further declined to approximately $45-55 \%$ and $35-50 \%$ at 48 and $72 \mathrm{~h}$, respectively. A significant increase in apoptotic cells was noted in NCI-H23 cells following MS13 treatment at $24 \mathrm{~h}(25-35 \%), 48$ and $72 \mathrm{~h}(45-55 \%)$. Higher apoptosis activity in NCI-H23 cells following MS13 treatment $(4 \mu \mathrm{M}$ and $8 \mu \mathrm{M})$ was observed at 48 and $72 \mathrm{~h}$ compared to $24 \mathrm{~h}$; however, a significant increase in necrotic cells ranging from 8 to $15 \%$ was also noted at these time points for $8 \mu \mathrm{M}$ MS13 treatment, whereas the percentage of necrotic cells at a dose of $4 \mu \mathrm{M}$ remained low, with approximately less than $5 \%$ at all time points.

\subsubsection{Quantification of Relative Caspase-3 Activity}

The relative caspase- 3 apoptotic activity was measured based on caspase- 3 activity from the treated cells against the untreated cells (control). As depicted in Figure 6A, NCI$\mathrm{H} 520$ cells only showed a significant increase in caspase- 3 activity at $10 \mu \mathrm{M}$ following $48 \mathrm{~h}$ of MS13 treatment. Meanwhile, there were no significant differences observed for the treated cells with $5 \mu \mathrm{M}$ at all time points. As for NCI-H23 cells (Figure 6B), MS13 treatment at both doses following 24 and $48 \mathrm{~h}$ treatment demonstrated a significant increase in caspase-3 activity compared to control, whereas after $72 \mathrm{~h}$ of MS13 treatment, only treated cells at $10 \mu \mathrm{M}$ showed a notable increase in caspase- 3 activity. Taken together, these results indicate that MS13 induces apoptosis by caspase-3 activity in both cell lines in which NCI-H520 demonstrated an increase in caspase- 3 activity at $10 \mu \mathrm{M}$ following $48 \mathrm{~h}$ of treatment while NCI-H23 cells displayed a significant increase in caspase- 3 activity at 24 and $48 \mathrm{~h}$ in a dose and time-dependent manner.
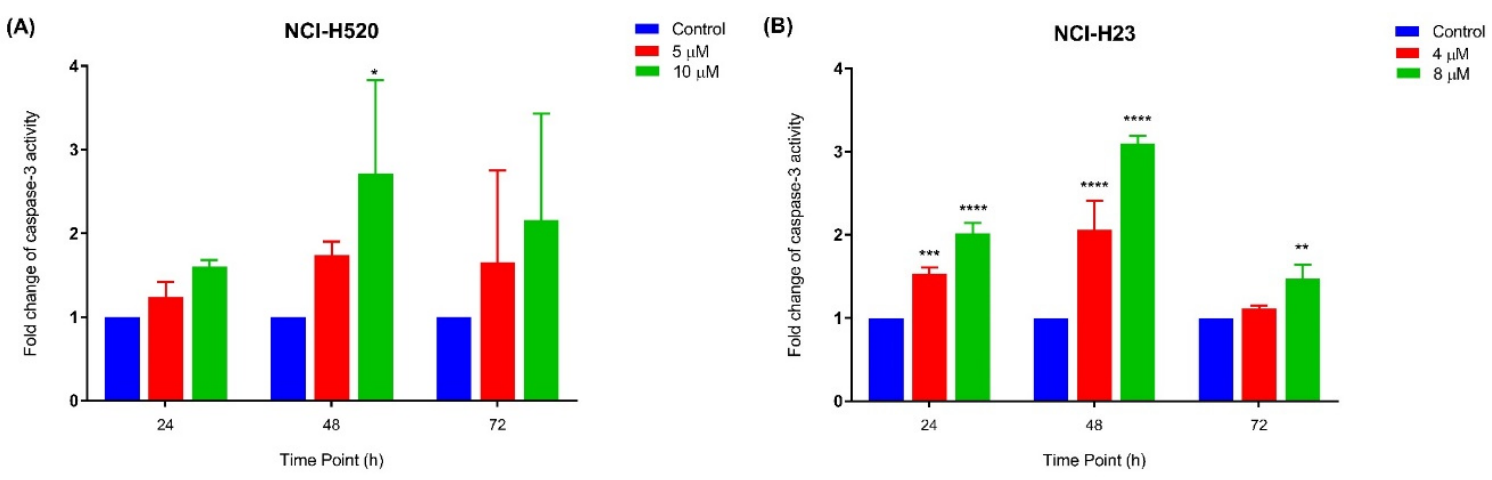

Figure 6. Relative caspase-3 activity in (A) NCI-H520 and (B) NCI-H23 cells treated with MS13 at different time points. Experiments were performed in triplicates and results compared between three independent experiments. Results are expressed as the ratio of means of caspase-3 activity of treated samples over untreated samples and comparison between data sets performed using ANOVA. Asterisks indicate statistically significant ${ }^{*}$ for $p<0.05,{ }^{* *}$ for $p<0.01,{ }^{* * *}$ for $p<0.001$ and ${ }^{* * *}$ for $\left.p<0.0001\right)$ differences between data sets for each treatment dose. 


\subsubsection{Quantification of Bcl-2 Protein Concentration}

The apoptotic activity of MS13 in NCI-H520 and NCI-H23 cells was further evaluated by assessing the $\mathrm{Bcl}-2$ protein concentration. The treatment of NCI-H520 (Figure 7A) and NCI-H23 (Figure 7B) cells with MS13 (NCI-H520: 5 and $10 \mu \mathrm{M}$; NCI-H23: 4 and $8 \mu \mathrm{M}$ ) demonstrated a significant and progressive decrease of $\mathrm{Bcl}-2$ concentration when treated for 24 to $72 \mathrm{~h}$.
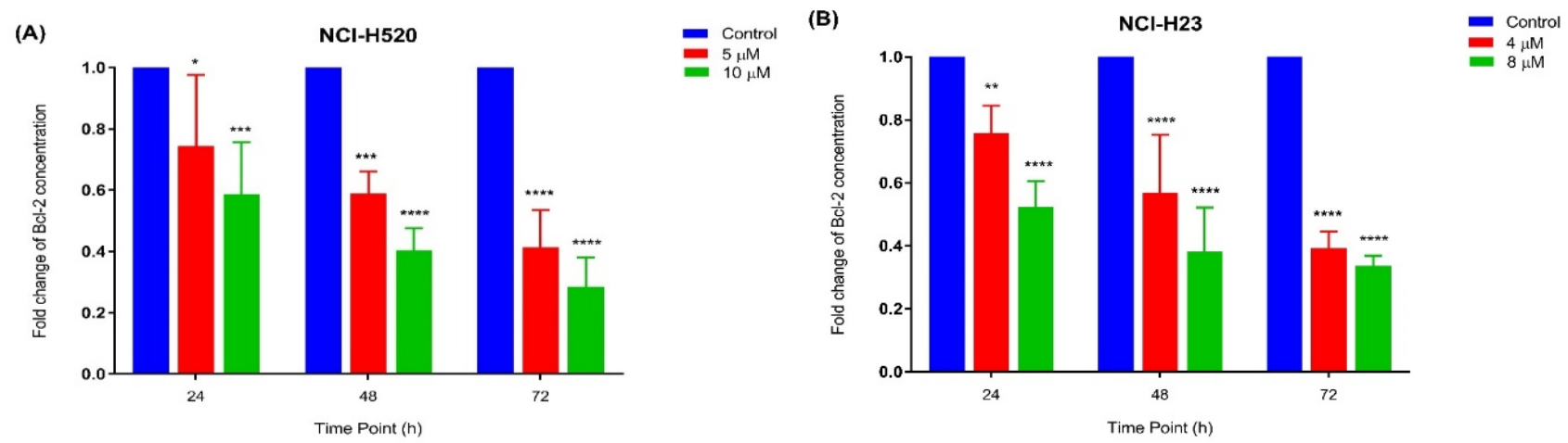

Figure 7. Fold change of Bcl-2 concentration in (A) NCI-H520 and (B) NCI-H23 cells treated with MS13 at different time points. Experiments were performed in triplicates and results compared between three independent experiments. Results are expressed as the ratio of means of Bcl-2 concentration of treated samples over untreated samples and comparison between datasets performed using ANOVA. Asterisks indicate statistically significant ${ }^{*}$ for $p<0.05,{ }^{* *}$ for $p<0.01{ }^{* * *}$ for $p<0.001$ and $^{* * * *}$ for $\left.p<0.0001\right)$ differences between data sets for each treatment dose.

\subsection{Analysis of Differentially Expressed Genes (DEGs) in MS13-Treated Lung Cancer Cells Associated with PI3K-AKT, Cell Cycle-Apoptosis, and MAPK Pathways}

We further evaluated the gene expression profile of selected signaling pathways in MS13-treated NCI-H520 and NCI-H23 lung cancer cells using nCounter PanCancer Pathways panel. Based on the dosages previously established to induce apoptosis, NCIH520 was treated with $10 \mu \mathrm{M}$ of MS13 for $24 \mathrm{~h}$, while NCI-H23 was treated with $4 \mu \mathrm{M}$ of MS13 for $48 \mathrm{~h}$. Only significant entities that demonstrated $p<0.05$ and differentially expressed compared to the control by a fold change greater than or equal to 1.3 (FC $\geq 1.3$ ) and fold change lower than or equal to -1.3 (FC $\leq-1.3$ ) were considered for analysis. The gene expression data showed a total of 22 significant DEGs that mutually expressed in both NCI-H50 and NCI-H23 cells treated with MS13. However, a total of 77 and 47 significant $(p<0.05)$ DEGs were exclusively expressed in NCI-H520 and NCI-H23 cells treated with MS13, respectively. The total significant DEGs were further grouped to their respective signaling pathways as described by the nCounter PanCancer Pathways Code set. The 13 cancer-related pathways were NOTCH, APC/Wnt, Hedgehog, chromatin modification, transcriptional regulation, DNA damage control, TGF-Beta, MAPK, JAKSTAT, PI3K-AKT, driver genes, cell cycle-apoptosis, and Ras signaling pathways. Our results showed that the DEGs expressed in NCI-H520 and NCI-H23 cells treated with MS13 were highly associated with PI3K-AKT, cell cycle-apoptosis, and MAPK pathways. As shown in Tables 2 and 3, these genes were associated with either a single pathway or multiple pathways. The findings showed that 12 DEGs were mutually expressed in both the cell lines, while 36 DEGs were exclusively expressed in NCI-H520 and 22 DEGs in NCI-H23 cells. 
Table 2. Upregulated DEGs in NCI-H520 and NCI-H23 cells in response to MS13 treatment.

\begin{tabular}{|c|c|c|c|c|c|}
\hline Genes/Cell Line & Gene Description & Accession No. & $\begin{array}{l}\text { Single/Multiple } \\
\text { Pathways }\end{array}$ & FC & $p$-Value \\
\hline \multicolumn{6}{|l|}{ NCI-H520 } \\
\hline PTEN & Phosphatase and Tensin Homolog & NM_000314.3:1675 & PI3K & 1.3 & 0.0233 \\
\hline DDIT4 & DNA Damage Inducible Transcript 4 & NM__019058.2:85 & PI3K & 1.4 & 0.0223 \\
\hline ENDOG & Endonuclease $\mathrm{G}$ & NM_004435.2:694 & Cell-cycle Apoptosis & 1.5 & 0.00367 \\
\hline CASP8 & Caspase 8 & NM_001228.4:301 & Cell-cycle Apoptosis & 1.4 & 0.0341 \\
\hline DDIT3 & DNA Damage Inducible Transcript 3 & NM_004083.4:40 & MAPK & 1.3 & 0.00325 \\
\hline CDKN1A & $\begin{array}{c}\text { Cyclin Dependent Kinase Inhibitor } \\
\text { 1A }\end{array}$ & NM_000389.2:1975 & $\begin{array}{c}\text { Cell-cycle Apoptosis and } \\
\text { PI3K }\end{array}$ & 2.1 & 0.0006 \\
\hline${ }^{*} \mathrm{CCND} 3$ & Cyclin D3 & NM_001760.2:1215 & $\begin{array}{c}\text { Cell-cycle Apoptosis and } \\
\text { PI3K }\end{array}$ & 1.4 & 0.015 \\
\hline GADD45G & $\begin{array}{l}\text { Growth Arrest and DNA Damage } \\
\text { Inducible Gamma }\end{array}$ & NM_006705.3:250 & $\begin{array}{c}\text { Cell-cycle Apoptosis and } \\
\text { MAPK }\end{array}$ & 2.1 & 0.000258 \\
\hline \multicolumn{6}{|l|}{ NCI-H23 } \\
\hline ITGA2 & Integrin Subunit Alpha 2 & NM_002203.2:475 & PI3K & 1.4 & 0.00405 \\
\hline THEM4 & Thioesterase Superfamily Member 4 & NM_053055.4:764 & PI3K & 1.3 & 0.00716 \\
\hline TNFRSF10A & $\begin{array}{c}\text { TNF Receptor Superfamily Member } \\
10 \mathrm{a}\end{array}$ & NM_003840.3:2380 & Cell-cycle Apoptosis & 1.4 & 0.00918 \\
\hline IRAK2 & $\begin{array}{c}\text { Interleukin } 1 \text { Receptor Associated } \\
\text { Kinase } 2\end{array}$ & NM_001570.3:1285 & Cell-cycle Apoptosis & 1.4 & 0.00186 \\
\hline DUSP2 & Dual Specificity Phosphatase 2 & NM_004418.3:1235 & MAPK & 1.3 & 0.0344 \\
\hline$* \mathrm{CCND} 3$ & Cyclin D3 & NM_001760.2:1215 & $\begin{array}{c}\text { Cell-cycle Apoptosis and } \\
\text { PI3K }\end{array}$ & 1.3 & 0.00733 \\
\hline
\end{tabular}

* Indicates mutually expressed DEGs in both NCI-H520 and NCI-H23 cells treated with MS13.

Table 3. Downregulated DEGs in NCI-H520 and NCI-H23 cells in response to MS13 treatment.

\begin{tabular}{|c|c|c|c|c|c|}
\hline Genes/Cell Line & Gene Description & Accession No. & $\begin{array}{l}\text { Single/Multiple } \\
\text { Pathways }\end{array}$ & FC & $p$-Value \\
\hline \multicolumn{6}{|l|}{ NCI-H520 } \\
\hline EPHA2 & EPH Receptor A2 & NM_004431.2:1525 & PI3K & -2.0 & 0.00397 \\
\hline NGFR & Nerve Growth Factor Receptor & NM_002507.1:2705 & PI3K & -2.0 & 0.00691 \\
\hline MYB & $\begin{array}{c}\text { MYB Proto-Oncogene, Transcription } \\
\text { Factor }\end{array}$ & NM_005375.2:3145 & PI3K & -1.9 & 0.00042 \\
\hline ITGB4 & Integrin Subunit Beta 4 & NM_001005731.1:4151 & PI3K & -1.7 & 0.00064 \\
\hline COL4A5 & Collagen Type IV Alpha 5 Chain & NM_033381.1:5360 & PI3K & -1.7 & 0.00275 \\
\hline * THBS1 & Thrombospondin 1 & NM_003246.2:3465 & PI3K & -1.7 & 0.00044 \\
\hline KIT & $\begin{array}{c}\text { KIT Proto-Oncogene, Receptor } \\
\text { Tyrosine Kinase }\end{array}$ & NM_000222.1:5 & PI3K & -1.6 & 0.0418 \\
\hline KITLG & KIT Ligand & NM_003994.4:1155 & PI3K & -1.5 & 0.00058 \\
\hline PDGFD & Platelet Derived Growth Factor D & NM_025208.4:1120 & PI3K & -1.4 & 0.0496 \\
\hline FN1 & Fibronectin 1 & NM_212482.1:1776 & PI3K & -1.3 & 0.00927 \\
\hline ITGA2 & Integrin Subunit Alpha 2 & NM_002203.2:475 & PI3K & -1.3 & 0.0199 \\
\hline * MCM-7 & $\begin{array}{l}\text { Minichromosome Maintenance } \\
\text { Complex Component } 7\end{array}$ & NM_182776.1:1325 & $\begin{array}{l}\text { Cell-cycle } \\
\text { Apoptosis }\end{array}$ & -4.3 & $1.62 \times 10^{-5}$ \\
\hline E2F1 & E2F Transcription Factor 1 & NM_005225.1:935 & $\begin{array}{l}\text { Cell-cycle } \\
\text { Apoptosis }\end{array}$ & -1.5 & 0.00051 \\
\hline MAP2K1 & $\begin{array}{c}\text { Mitogen-Activated Protein Kinase } \\
\text { Kinase } 1\end{array}$ & NM_002755.2:970 & $\begin{array}{l}\text { Cell-cycle } \\
\text { Apoptosis }\end{array}$ & -1.4 & 0.00012 \\
\hline CDKN2D & $\begin{array}{c}\text { Cyclin-Dependent Kinase Inhibitor } \\
\text { 2D }\end{array}$ & NM_001800.3:870 & $\begin{array}{l}\text { Cell-cycle } \\
\text { Apoptosis }\end{array}$ & -1.4 & 0.0333 \\
\hline CASP7 & Caspase 7 & NM_001227.3:915 & $\begin{array}{l}\text { Cell-cycle } \\
\text { Apoptosis }\end{array}$ & -1.3 & 0.0198 \\
\hline PKMYT1 & $\begin{array}{c}\text { Protein Kinase, } \\
\text { Membrane-Associated } \\
\text { Tyrosine/Threonine } 1\end{array}$ & NM_004203.3:780 & $\begin{array}{l}\text { Cell-cycle } \\
\text { Apoptosis }\end{array}$ & -1.3 & 0.00813 \\
\hline
\end{tabular}


Table 3. Cont.

\begin{tabular}{|c|c|c|c|c|c|}
\hline Genes/Cell Line & Gene Description & Accession No. & $\begin{array}{l}\text { Single/Multiple } \\
\text { Pathways }\end{array}$ & FC & $p$-Value \\
\hline HDAC10 & Histone Deacetylase 1 & NM_032019.5:932 & $\begin{array}{l}\text { Cell-cycle } \\
\text { Apoptosis }\end{array}$ & -1.3 & 0.00159 \\
\hline MYD88 & $\begin{array}{c}\text { Innate Immune Signal Transduction } \\
\text { Adaptor }\end{array}$ & NM_002468.3:2145 & $\begin{array}{l}\text { Cell-cycle } \\
\text { Apoptosis }\end{array}$ & -1.3 & 0.00872 \\
\hline *SKP2 & S-Phase Kinase-Associated Protein 2 & NM_005983.2:615 & $\begin{array}{l}\text { Cell-cycle } \\
\text { Apoptosis }\end{array}$ & -1.3 & 0.00401 \\
\hline CACNA2D2 & $\begin{array}{l}\text { Calcium Voltage-Gated Channel } \\
\text { Auxiliary Subunit Alpha2delta } 2\end{array}$ & NM_001005505.1:2045 & MAPK & -2.1 & 0.0113 \\
\hline CACNA1E & $\begin{array}{c}\text { Calcium Voltage-Gated Channel } \\
\text { Subunit Alpha1 E }\end{array}$ & NM_000721.2:9325 & MAPK & -2.1 & 0.00435 \\
\hline DUSP4 & Dual Specificity Phosphatase 4 & NM_057158.2:3115 & MAPK & -1.6 & 0.0319 \\
\hline MAP2K6 & $\begin{array}{c}\text { Mitogen-Activated Protein Kinase } \\
\text { Kinase } 6\end{array}$ & NM_002758.3:555 & MAPK & -1.5 & 0.00795 \\
\hline${ }^{*} \mathrm{MAPT}$ & Microtubule Associated Protein Tau & NM_016834.3:1205 & MAPK & -1.5 & 0.0469 \\
\hline THSBP1 & Heat Shock Factor Binding Protein 1 & NM_003246.2:3465 & MAPK & -1.5 & 0.0123 \\
\hline DUSP6 & Dual Specificity Phosphatase 6 & NM_001946.2:1535 & MAPK & -3.3 & $6.93 \times 10^{-5}$ \\
\hline RASGRP1 & RAS Guanyl Releasing Protein 1 & NM_005739.3:365 & MAPK & -1.7 & 0.0297 \\
\hline PIK3R2 & $\begin{array}{l}\text { Phosphoinositide-3-Kinase } \\
\text { Regulatory Subunit } 2\end{array}$ & NM_005027.2:3100 & $\begin{array}{c}\text { Cell } \\
\text { cycle-apoptosis } \\
\text { and PI3K }\end{array}$ & -1.5 & 0.00943 \\
\hline BAD & $\begin{array}{l}\text { BCL2 Associated Agonist of Cell } \\
\text { Death }\end{array}$ & NM_004322.3:652 & $\begin{array}{l}\text { Cell } \\
\text { cycle-apoptosis } \\
\text { and PI3K }\end{array}$ & -1.4 & 0.00012 \\
\hline CDK6 & Cyclin-Dependent Kinase 6 & NM_001259.5:15 & $\begin{array}{l}\text { Cell } \\
\text { cycle-apoptosis } \\
\text { and PI3K }\end{array}$ & -1.4 & 0.00398 \\
\hline PIK3R3 & $\begin{array}{l}\text { Phosphoinositide-3-Kinase } \\
\text { Regulatory Subunit } 3\end{array}$ & NM_003629.3:1800 & $\begin{array}{c}\text { Cell } \\
\text { cycle-apoptosis } \\
\text { and PI3K }\end{array}$ & -1.3 & 0.00023 \\
\hline * PIK3CB & $\begin{array}{c}\text { Phosphatidylinositol-4,5- } \\
\text { Bisphosphate 3-Kinase Catalytic } \\
\text { Subunit Beta }\end{array}$ & NM_006219.1:2945 & $\begin{array}{c}\text { Cell } \\
\text { cycle-apoptosis } \\
\text { and PI3K }\end{array}$ & -1.3 & 0.00023 \\
\hline FGF9 & Fibroblast Growth Factor 9 & NM_002010.2:1565 & PI3K and MAPK & -1.8 & 0.00742 \\
\hline PRKCA & Protein Kinase C Alpha & NM_002737.2:5560 & PI3K and MAPK & -1.6 & 0.0235 \\
\hline MAP2K1 & $\begin{array}{c}\text { Mitogen-Activated Protein Kinase } \\
\text { Kinase } 1\end{array}$ & NM_002755.2:970 & PI3K and MAPK & -1.4 & 0.000117 \\
\hline MAP2K2 & $\begin{array}{c}\text { Mitogen-Activated Protein Kinase } \\
\text { Kinase } 2\end{array}$ & NM_030662.2:1325 & PI3K and MAPK & -1.4 & 0.00258 \\
\hline * MAPK3 & Mitogen-Activated Protein Kinase 3 & NM_001040056.1:580 & $\begin{array}{l}\text { PI3K and MAPK } \\
\text { Cell }\end{array}$ & -1.3 & 0.016 \\
\hline * TGFB2 & Transforming Growth Factor Beta 2 & NM_003238.2:1125 & $\begin{array}{l}\text { cycle-apoptosis } \\
\text { and MAPK }\end{array}$ & -1.5 & 0.00123 \\
\hline PRKACA & $\begin{array}{l}\text { Protein Kinase CAMP-Activated } \\
\text { Catalytic Subunit Alpha }\end{array}$ & NM_002730.3:400 & $\begin{array}{c}\text { Cell } \\
\text { cycle-apoptosis, } \\
\text { PI3K and MAPK } \\
\text { Cell }\end{array}$ & -1.3 & $4.50 \times 10^{-5}$ \\
\hline AKT1 & AKT Serine/Threonine Kinase 1 & NM_005163.2:1772 & $\begin{array}{l}\text { cycle-apoptosis, } \\
\text { PI3K and MAPK }\end{array}$ & -1.3 & 0.0007 \\
\hline \multicolumn{6}{|l|}{ NCI-H23 } \\
\hline HGF & Hepatocyte Growth Factor & NM_000601.4:550 & PI3K & -1.8 & 0.0285 \\
\hline COL5A2 & Collagen Type V Alpha 2 Chain & NM_000393.3:4075 & PI3K & -1.7 & 0.00464 \\
\hline GNG4 & G Protein Subunit Gamma 4 & NM_004485.2:215 & PI3K & -1.6 & 0.028 \\
\hline MET & $\begin{array}{c}\text { MET Proto-Oncogene, Receptor } \\
\text { Tyrosine Kinase }\end{array}$ & NM_000245.2:405 & PI3K & -1.5 & 0.00293 \\
\hline ITGA3 & Integrin Subunit Alpha 3 & NM_005501.2:1138 & PI3K & -1.5 & 0.0131 \\
\hline * THBS1 & Thrombospondin 1 & NM_003246.2:3465 & PI3K & -1.4 & 0.00578 \\
\hline IRS1 & Insulin Receptor Substrate 1 & NM_005544.2:6224 & PI3K & -1.4 & 0.00412 \\
\hline EFNA3 & Ephrin A3 & NM_004952.4:1672 & PI3K & -1.4 & 0.0205 \\
\hline
\end{tabular}


Table 3. Cont.

\begin{tabular}{|c|c|c|c|c|c|}
\hline Genes/Cell Line & Gene Description & Accession No. & $\begin{array}{l}\text { Single/Multiple } \\
\text { Pathways }\end{array}$ & FC & $p$-Value \\
\hline EIF4EBP1 & $\begin{array}{l}\text { Eukaryotic Translation Initiation } \\
\text { Factor 4E Binding Protein } 1\end{array}$ & NM_001429.2:715 & PI3K & -1.3 & 0.0184 \\
\hline * MCM-7 & $\begin{array}{l}\text { Minichromosome Maintenance } \\
\text { Complex Component } 7\end{array}$ & NM_182776.1:1325 & $\begin{array}{l}\text { Cell-cycle } \\
\text { Apoptosis }\end{array}$ & -1.7 & 0.00101 \\
\hline CCNA1 & Cyclin A1 & NM_003914.3:1605 & $\begin{array}{l}\text { Cell-cycle } \\
\text { Apoptosis }\end{array}$ & -1.4 & 0.0264 \\
\hline SMAD2 & SMAD Family Member 2 & NM_001003652.1:4500 & $\begin{array}{l}\text { Cell-cycle } \\
\text { Apoptosis }\end{array}$ & -1.4 & 0.0199 \\
\hline CHEK2 & Checkpoint Kinase 2 & NM_007194.3:140 & $\begin{array}{l}\text { Cell-cycle } \\
\text { Apoptosis }\end{array}$ & -1.3 & 0.0398 \\
\hline MAD2L2 & Mitotic Arrest Deficient 2 Like 2 & NM_001127325.1:290 & $\begin{array}{l}\text { Cell-cycle } \\
\text { Apoptosis }\end{array}$ & -1.3 & 0.0128 \\
\hline *SKP2 & S-Phase Kinase Associated Protein 2 & NM_005983.2:615 & $\begin{array}{l}\text { Cell-cycle } \\
\text { Apoptosis }\end{array}$ & -1.3 & 0.00026 \\
\hline CDC7 & Cell Division Cycle 7 & NM_003503.2:805 & $\begin{array}{l}\text { Cell-cycle } \\
\text { Apoptosis }\end{array}$ & -1.3 & 0.0302 \\
\hline RAD21 & $\begin{array}{l}\text { RAD21 Cohesin Complex } \\
\text { Component }\end{array}$ & NM_006265.2:1080 & $\begin{array}{l}\text { Cell-cycle } \\
\text { Apoptosis }\end{array}$ & -1.3 & 0.0289 \\
\hline * MAPT & Microtubule Associated Protein Tau & NM_016834.3:1205 & MAPK & -1.5 & 0.0469 \\
\hline RAC3 & Rac Family Small GTPase 3 & NM_005052.2:702 & MAPK & -1.4 & 0.0439 \\
\hline FLNA & $\begin{array}{l}\text { Filamin A } \\
\text { Phosphatidylinositol-4 5- }\end{array}$ & NM_001456.3:7335 & $\begin{array}{l}\text { MAPK } \\
\text { Cell }\end{array}$ & -1.3 & 0.00262 \\
\hline * PIK3CB & $\begin{array}{c}\text { Bisphosphate 3-Kinase Catalytic } \\
\text { Subunit Beta }\end{array}$ & NM_006219.1:2945 & $\begin{array}{c}\text { cycle-apoptosis } \\
\text { and PI3K } \\
\text { Cell }\end{array}$ & -1.3 & 0.0272 \\
\hline FAS & Fas Cell Surface Death Receptor & NM_152876.1:1740 & $\begin{array}{l}\text { cycle-apoptosis } \\
\text { and MAPK }\end{array}$ & -1.4 & 0.00328 \\
\hline РРРЗСА & $\begin{array}{c}\text { Protein Phosphatase } 3 \text { Catalytic } \\
\text { Subunit Alpha }\end{array}$ & NM_000944.4:3920 & $\begin{array}{c}\text { Cell } \\
\text { cycle-apoptosis } \\
\text { and MAPK } \\
\text { Cell }\end{array}$ & -1.3 & 0.0223 \\
\hline * TGFB2 & Transforming Growth Factor Beta 2 & NM_003238.2:1125 & $\begin{array}{l}\text { cycle-apoptosis } \\
\text { and MAPK }\end{array}$ & -1.6 & 0.0104 \\
\hline FGFR2 & Fibroblast Growth Factor Receptor 2 & NM_000141.4:647 & PI3K and MAPK & -1.6 & 0.0265 \\
\hline FGF2 & Fibroblast Growth Factor 2 & NM_002006.4:620 & PI3K and MAPK & -1.4 & 0.00307 \\
\hline FGFR4 & Fibroblast Growth Factor Receptor 4 & NM_002011.3:1585 & PI3K and MAPK & -1.3 & 0.027 \\
\hline * MAPK3 & Mitogen-Activated Protein Kinase 3 & NM_001040056.1:580 & $\begin{array}{c}\text { PI3K and MAPK } \\
\text { Cell }\end{array}$ & -1.4 & 0.0425 \\
\hline TP53 & Tumor Protein P53 & NM_000546.2:1330 & $\begin{array}{l}\text { cycle-apoptosis, } \\
\text { PI3K and MAPK }\end{array}$ & -1.3 & 0.00783 \\
\hline
\end{tabular}

* Indicates mutually expressed DEGs in both NCI-H520 and NCI-H23 cells treated with MS13.

For the purpose of discussion, we selected the DEGs that demonstrated a fold change greater than or equal to 1.5 ( $F C \geq 1.5$ ) and fold change lower than or equal to -1.5 (FC $\leq-1.5)$. Among the mutually expressed DEGs, MCM7 associated with cell cycleapoptosis, THBS1 with PI3K, MAPT with MAPK, and TGFB2 with cell cycle-apoptosis and MAPK were downregulated in both NCI-H520- and NCI-H23-treated cells. The DEG exclusively upregulated in NCI-H520 treated cells was ENDOG associated with cell cycle-apoptosis pathway. Meanwhile, exclusively downregulated DEGs included EPHA2, NGFR, MYB, ITGB4, COL4A5, KIT, and KITLG were associated with PI3K-AKT pathway, CACNA2D2, CACNA1E, DUSP4, MAP2K6, HSBP1, DUSP6, and RASGRP1 with MAPK pathway, and E2F1 with cell cycle-apoptosis pathway. Several exclusive DEGs expressed in MS13 treated-NCI-H520 cells were also associated with multiple pathways such as CDKN1A and PIK3R2 (cell cycle-apoptosis and PI3K-AKT pathways); GADD45G (cell cycle-apoptosis and MAPK pathways) and FGF9 and PRKCA (PI3K-AKT and MAPK pathways). In NCI-H23 cells treated with MS13, the exclusively downregulated DEGs were 
HGF, COL5A2, GNG4, MET, and ITGA3 associated with the PI3K-AKT pathway. Additionally, FGFR2, which is associated with multiple pathways (PI3K-AKT and MAPK pathways), was also exclusively downregulated in NCI-H23 cells following MS13 treatment.

\section{Discussion}

Our study showed that MS13 exhibited greater cytotoxicity and growth inhibitory effect in a dose-dependent manner at lower concentrations compared to the parent compound, curcumin, in both NCI-H520 and NCI-H23 cells. For cytotoxicity assay, the incubation time for MS13 treatment in NCI-H520 and NCI-H23 cells was selected as $72 \mathrm{~h}$. Based on the doubling time of NCI-H520 and NCI-H23 cells, $72 \mathrm{~h}$ was the optimum time required for a maximal cytotoxic activity to occur compared to 24 and $48 \mathrm{~h}$. MS13 was observed to have an increased inhibitory effect on NCI-H520 and NCI-H23 cells by approximately 5 times compared to curcumin based on the $\mathrm{EC}_{50}$ values. Previously, studies conducted by Citalingam et al. (2015), Paulraj et al. (2015), and Ismail et al. (2020), treating human prostate, cervical, and colon cancer cells with MS13, demonstrated greater inhibition effect with lower $\mathrm{EC}_{50}$ values compared to curcumin [19-21]. Similarly, previous studies also observed that colon, pancreatic, and gastric cancer cells treated with FLLL-11 [15,25] and GO-Y022 [26], which has identical structure as MS13 showed lower IC 50 values compared to curcumin by several fold. In addition, other DAPs such as HO-3867 [16,27], EF24 [17,28], and GO-Y030 $[29,30]$ demonstrated reduction in cell viability of human lung cancer cells compared to curcumin. It was also observed that NCI-H23 cells exhibited lower $\mathrm{EC}_{50}$ values compared to NCI-H520 cells following MS13 treatment. This finding suggests that NCI-H520 and NCI-H23 demonstrated differing sensitivities to MS13. This could be the result of being derived from different sources, as NCI-H520 is a squamous cell carcinoma while NCI-H23 is an adenocarcinoma. We believe that the different derivation of NCI-H520 and NCI-H23 may result in different biological, behavioral, and cell morphological characteristics which could contribute to the $\mathrm{EC}_{50}$ values noted upon MS13 treatment. Our results showed that SX values of MS13 treatment on NCI-H520 and NCI-H23 were above 100 indicating that MS13 is more selective towards lung cancer cells over the normal cells.

Antiproliferative assay was also performed over three time points $(24,48$, and $72 \mathrm{~h}$ ) to observe the dose and time-dependent effect of MS13 on NCI-H23 and NCI-H520 cells. The results revealed that MS13 caused a notable decline in cell viability of both cell lines as the time exposure and treatment dosage increased indicating inhibition of cell proliferation rate in a dose- and time-dependent manner. Vehicle-treated (DMSO) control cells demonstrated increased cell proliferation over time, while treatment with MS13 appears to have a significant inhibitory effect especially at later time points. The NCI-H520 cells displayed a substantial decrease of cell viability at $3.1 \mu \mathrm{M}$ onwards for 48 and $72 \mathrm{~h}$ and at $6.3 \mu \mathrm{M}$ onwards for $24 \mathrm{~h}$. On the other hand, NCI-H23 cells showed a significant decrease of cell viability at $3.1 \mu \mathrm{M}$ onwards for all time points. Thus, it can be suggested that MS13 treatment on NCI-H23 showed greater antiproliferative effect than NCI-H520 cells indicating different characteristics of cells respond differently to a treatment. Besides, curcumin was observed to exert an antiproliferative effect at a higher dosage of $25 \mu \mathrm{M}$ onwards on both NCI-H520 and NCI-H23 lung cancer cells at all time points compared to MS13. Furthermore, it was observed that in all cases, MS13 treatment demonstrated greater growth inhibition compared to curcumin at 24,48 , and $72 \mathrm{~h}$.

The enhanced cytotoxic and antiproliferative effects of MS13 against NCI-H520 and NCI-H23 cells compared to curcumin was believed due to the modification of the middle structure of curcumin which is the removal of $\beta$-diketone and substituents of $3^{\prime}$ methoxy$4^{\prime}$-hydroxy on the phenyl rings [18,31]. It has been reported that the instability as well as decomposition of curcumin affected by alkaline $\mathrm{pH}$ and light exposure were caused by the active methylene moiety while the biological effects of curcumin were due to the role of hydroxy moiety at the aromatic rings [32]. Therefore, MS13 with mono-ketone derivative carrying $\alpha$ - and $\beta$-unsaturated ketone moiety is more stable and cause improved cytotoxicity and antiproliferative effects compared to curcumin. 
Dysregulation in apoptotic pathways has been demonstrated to result in tumor cell formation as it creates a permissive environment for genetic pathway instability and accumulation of mutations [33]. Therefore, molecular pathway of apoptosis is regarded as the most potent strategy to counter the cancerous growth [34]. In the present study, morphological analysis and biochemical assays such as caspase 3 and bcl-2 were performed to determine the effect of MS13 on induction of apoptosis in NCI-H520 and NCI-H23 lung cancer cells. For apoptotic assays, MS13 at a dose of $\mathrm{EC}_{50}$ and $2 \times \mathrm{EC}_{50}$ were treated on both cell lines at various time points (24, 48, and $72 \mathrm{~h}$ ). Morphological analysis on apoptotic activity of MS13-treated NCI-H520 and NCI-H23 cells was performed using acridine orange $(\mathrm{AO})$ and propidium iodide (PI) double staining method. Higher apoptotic activity of NCI-H520 and NCI-H23 cells treated with MS13 was observed at 48 and $72 \mathrm{~h}$ compared to $24 \mathrm{~h}$ for both dosages. Fluorescence microscopy analysis at $24 \mathrm{~h}$ revealed that NCI-H520 and NCI-H23 cells were stained bright green-yellow following treatment with both the doses, indicating induction of early apoptosis. Upon $48 \mathrm{~h}$ of MS13 treatment on both cells, there was a mixed population of cells with a larger proportion of early apoptotic cells compared to late suggesting that both early and late apoptotic events took place in both treated cells. Increase in late apoptotic cells and appearance of necrotic cells at $72 \mathrm{~h}$ of treatment resulted in higher percentage of cells stained bright orange-red. Nonetheless, the percentage of necrotic cells in both cells treated with MS13 at all doses remained low with less than $15 \%$ of total cell population. Taken together, these findings suggest that MS13 treatment at both doses induced apoptosis in NCI-H520 and NCI-H23 cells in dose and time-dependent manner with low percentage of necrotic cells.

Induction of apoptosis on lung cancer cells by MS13 treatment was further determined by caspase- 3 activity and Bcl-2 protein concentration level. Caspase- 3 is a cysteine protease that is activated early in a sequence of events associated with programmed cell death or apoptosis [35]. Activation of caspase-3 leads to cleavage of key substrate within the cell that is responsible to induce apoptosis eventually results in DNA degradation as well as morphological changes including cell blebbing, cell shrinkage, and chromatin condensation [36]. The present data showed that the increase in caspase- 3 activity is dose-dependent with a significant increase being noted in NCI-H520 cells following MS13 treatment at a higher dose of $10 \mu \mathrm{M}$ for $48 \mathrm{~h}$. However, in NCI-H23 treated cells a significant increase was noted from 24 to $48 \mathrm{~h}$ but peaked at $48 \mathrm{~h}$ for both doses. Previous studies reported that MS13 induced apoptosis by caspase-3 activation in human cervical, prostate, and colon cancer cells [19-21] Similarly, diarylpentanoids FLLL11 [15] and B19 [37] were shown to induce apoptosis in human colorectal cancer and ovarian cancer cells by increasing caspase-3 activity, respectively. Bcl-2 is a key protein in apoptosis induction by regulating mitochondrial membrane permeability and integrity, in addition to suppress cytochrome $c$ release [38]. It has been reported that a decrease in bcl-2 levels leads to cell death by apoptosis while overexpression of bcl-2 protects cells from death [38,39]. NCI-H520 and NCI-H23 cells treated with MS13 for both doses at 24, 48, and $72 \mathrm{~h}$ exhibited a significant decrease in bcl-2 protein concentration compared to the untreated in dose and time-dependent manner. Previous studies reported similar findings that DAPs GO-Y030 [30] and DM1 [40] decreased bcl-2 protein concentration in colon cancer and melanoma cells, respectively. Therefore, our findings suggest that MS13 mediates the apoptotic activity in NCI-H520 and NCI-H23 lung cancer cells through the activation of caspase- 3 and reduction of bcl-2 protein.

Gene expression analysis data showed that MS13 induced apoptosis in NCI-H520 and NCI-H23 cells by modulating genes associated with PI3K-AKT, cell cycle-apoptosis, and MAPK pathways. These signaling pathways play an essential role in the regulation of fundamental cellular functions such as transcription, translation, proliferation, growth, and survival. Accumulating evidences have shown that deregulation of these pathways is highly associated with various tumor development, including lung cancer. Previous studies demonstrated that the PI3K-Akt pathway is deregulated in lung cancer and has been associated with high-grade tumors, advanced disease, and poor prognosis [41]. Alteration of PI3K/Akt/mTOR pathway was found in 50-70\% of NSCLC cases [42-44] and 
approximately $36 \%$ of SCLC cases [45]. Besides, the MAPK pathway also includes several proto-oncogenes and is deregulated in $\sim 35 \%$ of lung cancer cases [46].

Our findings showed MCM7 (cell-cycle apoptosis), THBS1 (PI3K-AKT), MAPT (MAPK), and TGFB2 (cell-cycle apoptosis and MAPK) were mutually downregulated in NCI-H520 and NCI-H23 cells treated with MS13. The small number of mutual DEGs could be attributed to different biological and behavioral characteristic of NCI-H520 (squamous cell carcinoma) and NCI-H23 (adenocarcinoma) cells. MCM7 encodes minichromosome maintenance complex component 7 that is essential for the initiation and elongation of DNA replication [47]. MCM7 was associated with tumor development and progression in many cancers, including lung cancer [48-51]. Previous study reported that curcumin decreased the cell viability and altered the cell cycle of retinoblastoma cells by downregulating MCM7 [52]. MAPT codifies a microtubule-associated protein that promotes tubulin assembly and microtubule stabilization [53]. Overexpression of MAPT in colorectal [54], breast [55], and gastric [56] cancers was associated with tumor progression and poor prognosis. Previous study reported that higher expression of MAPT was detected in metastatic compared to primary prostate cancer patients [57]. TGFB2 encodes transforming growth factor-beta 2 protein that plays an important role in regulating cell proliferation, differentiation, motility, apoptosis, and immune regulation [58-60]. In renal cell carcinoma, knockdown of TGFB2 inhibited cell proliferation, migration, and invasion [61]. THBS1 encodes thrombospondin 1 (TSP1) protein which was shown to regulate cell growth and proliferation, cell motility, and cytoskeletal organization [62]. Previous studies have reported that TSP1 promoted angiogenesis, cell migration, and invasion in breast cancer cells $[63,64]$. The findings suggest that downregulation of MCM7, MAPT, TGFB2, and THBS1 by MS13 may inhibit cell proliferation and growth as well as metastasis and invasion in squamous cell carcinoma and adenocarcinoma NSCLC cells.

Our data demonstrated that ENDOG (cell cycle-apoptosis), CDKN1A (cell cycleapoptosis and PI3K-AKT) and GADD45G (cell cycle-apoptosis and MAPK) genes were exclusively upregulated in MS13 treated NCI-H520 cells. The ENDOG gene encodes an apoptotic mitochondrial endonuclease $\mathrm{G}$ that translocates to the nucleus during apoptosis [65]. The ENDOG expression has been correlated with cancer cells sensitivity towards chemotherapeutic agents. ENDOG-positive breast cancer cells were more sensitive to chemotherapeutic agents compared to ENDOG-negative breast cancer cells [66]. Silencing ENDOG in ENDOG-positive prostate cancer cells decreased its sensitivity to chemotherapeutic agents [67]. This suggest that upregulation of ENDOG may increase sensitivity of NCI-H520 in response to MS13 treatment. Cyclin-Dependent Kinase Inhibitor 1A (CDKN1A), also known as p21 or WAF1, plays an important role in cell differentiation, proliferation, and apoptosis via regulating cell cycle $[68,69]$. Decreased expression of CDKN1A facilitates cell cycle progression from the G1 to $S$ phase, thus promoting tumor cell proliferation $[70,71]$. Downregulation of CDKN1A was noted in several cancers including lung cancer [72-74] but upregulation of CDKN1A by various anticancer agents was reported to inhibit cell proliferation $[75,76]$. Curcumin inhibited cell proliferation in hepatocellular carcinoma cells through upregulation of CDKN1A [77]. Thus, we suggest that MS13 may inhibit cell proliferation in NCI-H520 cells through the upregulation of CDKN1A. GADD45G is a part of the growth arrest DNA damage-inducible gene (Gadd45g) family involved in DNA damage response and cell growth arrest [78]. Downregulation of GADD45G by aberrant promoter methylation has been noted in esophageal, colorectal, pancreatic, cervical, and lung cancer $[79,80]$. Decreased expression of GADD45G in esophageal cell carcinoma was correlated with tumor progression, metastasis and poor prognosis [81]. The study reported that GADD45G might act as a tumor suppressor gene and upregulation inhibits cell proliferation [81]. Therefore, MS13 may inhibit cell proliferation and metastasis in NCI-H520 cells through the upregulation of GADD45G.

Our results also showed that MS13 exclusively down-regulated EPHA2, ITGB4, COL4A5, KIT, KITLG, NGFR, and MYB, associated with PI3K-AKT pathway in NCI-H520 cells. The EPHA2, ITGB4, and COL4A5 genes have been associated with tumor progression 
by exhibiting cell invasion and metastasis. The EPHA2 gene encoding erythropoietinproducing hepatocellular A2 (EphA2) plays a significant role in cancer progression through neovascularization [82] while silencing of EPHA2 in human gastric cancer cells in vitro and in vivo decreased cell invasion, thus inhibiting cancer cell progression [83]. Curcumin was shown to inhibit tumor growth and angiogenesis in melanoma cells by downregulating EPHA2 [84]. ITGB4 encodes integrin $\alpha 6 \beta 4$ that regulates cell growth, motility, migration, invasion, and survival [85,86]. Aberrant expression of ITGB4 in lung [87], breast [88], and colorectal [89] cancers was associated with poor prognosis. Integrin $\alpha 6 \beta 4$ has been reported to stimulate cell invasion and metastasis in cancer cells through angiogenesis [90]. The COL4A5 gene encodes one of the Type IV collagen components that also plays a crucial role in angiogenesis, tissue remodeling, and cancer progression [91,92]. Col IV $\alpha 5$ deficiency delayed tumor progression in $\alpha 5$ (IV)-deficient mouse model with lung tumor [93]. Therefore, the downregulation of EPHA2, ITGB4, and COL4A5 by MS13 in NCI-H520 may inhibit cell progression, metastasis, invasion, and angiogenesis. KIT encodes the tyrosine kinase receptor for kit ligand, also known as stem cell factor encoded by the KITLG gene. The interaction between KIT and KITLG plays an important role in normal cellular functions such as cell proliferation, differentiation, migration, and apoptosis as well as in tumorigenesis [94,95]. Krasagakis et al. noted that overexpression of both c-KIT and KITLG in Merkel cell carcinoma increased cell proliferation and decreased apoptosis [96]. This suggests that MS13 may inhibit cell proliferation and induce apoptosis by downregulating KIT and KITLG in NCI-H520 cells. NGFR codifies neurotrophin receptor that belongs to the tumor necrosis factor receptor superfamily [97]. It functions as either a promoter or suppressor of tumorigenesis. High expression of NGFR in melanoma [98,99], thyroid [100], and lung cancers [101] promoted cell proliferation and metastasis while reduced expression in liver [102], prostate [103], gastric [104], and bladder [105] cancers induced apoptosis. MYB encodes a transcription factor that regulates cell proliferation and cell differentiation [106]. Increased expression of MYB in colon cancer [107,108], breast cancer [109,110], and leukemias $[111,112]$ was associated with cell proliferation, metastasis, and invasion. Therefore, MS13 may induce apoptosis while inhibit cell proliferation, metastasis and invasion in NCI-H520 cells by downregulating NGFR and MYB, respectively.

Our results showed that MAP2K6, HSBP1, RASGRP1, CACNA2D2, CACNA1E, DUSP4, and DUSP6 associated with MAPK pathway were downregulated in MS13 treatedNCI-H520 cells. The MAP2K6 gene encodes Mitogen-Activated Protein Kinase Kinase 6 (MAPKK6 also known as MKK6) acts as an upstream regulator of p38 MAPK signaling pathway $[113,114]$. Activation of $\mathrm{p} 38$ MAPK pathway has been shown to exert protumorigenic effect in prostate, esophageal, stomach, and colon cancers $[115,116]$. Overexpression of MKK6 was detected in 28\% esophageal carcinoma biopsies and silencing the gene inhibited esophageal cancer cell proliferation [117]. Therefore, MS13 may inhibit cell proliferation in NCI-H520 cells by downregulating MAP2K6. HSBP1 encodes heat shock binding protein (HSBP1) which interacts with the heat shock factor (HSF1) and represses its transcriptional activity $[118,119]$. Shen et al. (2014) found that HSBP1 was overexpressed in oral squamous cell carcinoma (OSCC) tissue compared with its adjacent normal tissue. In this study, HSBP1-overexpressing cells showed resistance to radiotherapy, while HSBP1-repressed cells showed increased sensitivity to radiotherapy both in vivo and in vitro, suggesting that HSBP1 is critical for radioresistance of OSCC cells [120]. Therefore, the downregulation of HSBP1 by MS13 may contribute by increasing its sensitivity towards radiotherapy treatment. CACNA2D2 and CACNA1E encode calcium voltage-gated channel subunit alpha 2 delta $2(\alpha 2 \delta 2)$ and alpha 1e $(\alpha 1$ e), respectively. The calcium ion channels play a crucial role in cell proliferation, differentiation, metastasis, and apoptosis [121]. Previous findings showed that CACNA2D2 promote tumorigenesis by stimulating cell proliferation and angiogenesis in prostate [122] and breast cancer [123] while CACNA1E was upregulated in lung squamous cell carcinoma [124] and wilms tumor [125]. Therefore, downregulation of CACNA2D2 and CACNA1E by MS13 may inhibit cell proliferation and metastasis and induce apoptosis in NCI-H520 cells. DUSP4 and DUSP6 genes encode Dual Specificity 
Protein Phosphatase and are members of the mitogen-activated protein kinase phosphatase (MKP) family that regulates the MAPK pathway [126]. Both DUSP4 and DUSP6 have been shown to induce cell proliferation, differentiation, and apoptosis [126-128]. The downregulation of DUSP4 in gastric cancer activated p53 signaling pathway, thus inducing apoptosis and cell cycle arrest at G2/M phase [129]. Additionally, overexpression of DUSP6 increased anchorage independent growth and invasion ability in immortal mouse melanocyte cell lines [130]. Our findings suggest that downregulation of both DUSP4 and DUSP6 by MS13 in NCI-H520 cells may induce apoptosis and inhibit cell growth and proliferation.

In our finding, the E2F1 gene associated with cell cycle-apoptosis pathway was downregulated by MS13 in NCI-H520 cells. E2F1 encodes one of the E2F protein family members that acts as a transcription factor and regulates G1/S phase transition [131]. Previous in vitro studies demonstrated that E2F1 has a tumor-promoting effect in lung [132,133], breast [134], and thyroid cancers [135]. Huang et al. (2007) revealed that E2F1 was positively correlated with thymidylate synthase (TS) and Survivin gene expressions in NSCLC. TS has been associated with tumor cell proliferation, chemotherapy resistance and poor prognosis but survivin gene with inhibition of apoptosis in NSCLC patients [136]. Therefore, the downregulation of E2F1 by MS13 may promote apoptosis and inhibit cell proliferation in NCI-H520 cells. Our findings also showed that PIK3R2 (cell cycle-apoptosis and PI3K pathways) and PRKCA (PI3K and MAPK pathways) associated with multiple pathways were downregulated in NCI-H520 cells treated with MS13. PIK3R2, a gene encoding p58 $\beta$ regulatory subunits that participated in most of the cancer-related and biological activity signaling pathways including PI3K, mTOR and cell cycle-apoptosis $[137,138]$. Elevated expression of p58 $\beta$ was noted in colon and breast cancers and positively associated with cell transformation, cell invasion, and tumor progression [139]. Hence, MS13 may inhibit cell transformation and invasion by downregulating PIK3R2 in NCI-H520 cells. PRKCA, a member of PKC family that plays a key role in regulating cell proliferation, survival and metastasis in cancers $[140,141]$. It has been indicated that PRKCA was highly elevated in NSCLC cells and associated with cell migration. Knockdown of PRKCA was shown to reduce the migration of NSCLC cells A549 compared to control cells [142]. Additionally, PRKCA expression was elevated in lung adenocarcinoma and positively associated with $\mathrm{T}$ classification, $\mathrm{N}$ classification, lymph node metastasis [143]. Thus, this finding suggests that the downregulation of PRKCA gene may inhibit cell metastasis and invasion in NCI-H520 cells.

Our results showed that MS13 downregulated HGF, MET, COL5A2, GNG4, and ITGA3 associated with PI3K-AKT pathway but FGFR2 was associated with multiple pathways (PI3K-AKT and MAPK) in NCI-H23 cells. HGF encodes a potent angiogenic cytokine that plays a vital role in angiogenesis by cooperating with vascular endothelial growth factor $[144,145]$. It has been indicated that HGF facilitates activation of MET signaling pathway [145] and our finding showed that MET was also downregulated in MS13-treated NCI-H23 cells. MET encodes c-Met, a tyrosine kinase receptor for HGF. Overexpression of c-Met was associated with cell proliferation, reduced apoptosis, angiogenesis, altered cytoskeletal function, and metastasis in some tumors including NSCLC [146-148]. Similarly, overexpression of HGF and/or its receptor c-Met have been reported in lung cancer cell lines and patients $[149,150]$. Curcumin was shown to inhibit epithelial-mesenchymal transition (EMT) and angiogenesis in HGF-induced lung cancer cells by regulating c-Metdependent PI3K/Akt/mTOR signaling pathways [151]. Thus, it can be suggested that the downregulation of MET and HGF by MS13 may inhibit EMT and angiogenesis in NCI-H23 cells. COL5A2, a gene encoding a collagen type $V \alpha-2$ chain has been associated with extracellular matrix organization, vascularization, EMTs process, invasion and metastasis in colorectal [152], breast [153], and bladder [154] cancers, and osteosarcoma [155]. Additionally, upregulation of COL5A2 was observed in lung adenocarcinoma compared to normal lung cells [156]. This suggests MS13 may inhibit cell invasion and metastasis of NCI-H23 cells through the downregulation of COL5A2. ITGA3 gene encodes an integrin alpha-3 subunit protein that serves as a cell surface adhesion molecule [157]. Increased expression of ITGA3 was noted in bladder, colorectal, pancreatic, prostate, nasopharyngeal carcinoma, 
and NSCLC cancers. Its elevated expression correlated with cancer metastasis through its interaction with extracellular matrix proteins [87,158-162]. Curcumin was reported to downregulate ITGA3 in lung cancer cells and cause inhibition of cell proliferation and invasion and induction of apoptosis [163]. Therefore, downregulation of ITGA3 by MS13 may inhibit cell proliferation and invasion and induce apoptosis in NCI-H23 cells. GNG4 encodes a member protein of the $G$ protein family that involved in cancer development and growth [164-166]. Upregulation of GNG4 in lung [124], colon [167], and gastric [166] cancers was positively correlated with cell metastasis and poor prognosis. FGFR2 encodes two isoforms FGFR2b and FGFR2 $c$ and its activation is associated with angiogenesis and metastasis [168]. Li et al. (2018) demonstrated that FGFR2 expression was upregulated in cancer tissues compared to the adjacent normal tissues. The elevated expression of FGFR2 was correlated with lymph node metastasis and TNM stage, indicating its association with tumor invasion and metastasis [169]. This indicates that downregulation of GNG4 and FGFR2 by MS13 may inhibit cell invasion and metastasis in NCI-H23 cells.

\section{Materials and Methods}

\subsection{Cell Culture and Maintenance}

Two human lung cancer cell lines NCI-H520 (squamous cell carcinoma) and NCI-H23 (adenocarcinoma) as well as normal cell line MRC-9 (human lung fibroblast cells) were purchased from the American Type Culture Collection (ATCC, Manassas, VA, USA). Both NCI-H520 and NCI-H23 cell lines were grown in RPMI 1640 media while the MRC-9 cell line was grown in Eagle's Minimum Essential Medium (EMEM, Gibco, Grand Island, NY, USA). All of the cell lines were maintained in respective media supplemented with $10 \%$ fetal bovine serum (FBS, Gibco) and 1\% penicillin $(100 \mathrm{U} / \mathrm{mL}) /$ streptomycin $(100 \mu \mathrm{g} / \mathrm{mL})$ (Gibco) in a humidified atmosphere with $5 \% \mathrm{CO}_{2}$ at $37^{\circ} \mathrm{C}$. For sustaining the growth of the cells, the medium in the flask was changed at every two-three-day interval until $80-90 \%$ of growth confluency was achieved. Upon achieving $90 \%$ confluency, the cells were subcultured using accutase (Gibco) as the cell detachment solution. All of the cell culture procedures were performed in a biosafety cabinet and appropriate aseptic techniques were adhered strictly to prevent contamination.

\subsection{Preparation of Curcumin Analogue (MS13) and Curcumin}

Curcumin analog 1,5-bis(4-hydroxy-3-methoxyphenyl)-1,4-pentadien-3-one (MS13) was synthesized by coupling aromatic aldehyde with acetone and cyclohexone via basecatalyzed aldol condensation, in a 1:2 ratio of ketone to aldehyde [170]. Commercially available curcumin (Sigma-Aldrich, St. Louis, MA, USA) was used as a control against lung cancer as well as normal cell lines. Both MS13 and curcumin stock solution (50 mM) were prepared in dimethyl sulfoxide (DMSO, Sigma Aldrich, St. Louis, MA, USA).

\subsection{Cell Viability and Antiproliferative Assays}

Briefly, the cells were seeded in a flat-bottomed microtiter 96-well plates at concentration of 80,000 cells $/ \mathrm{mL}$ with appropriate culture media in triplicates. Then, the cells were incubated in a $5 \% \mathrm{CO}_{2}$ incubator at $37{ }^{\circ} \mathrm{C}$ overnight to allow the cells to adhere to the bottom of the wells. After $24 \mathrm{~h}$, the media was aspirated off and replaced with fresh media containing curcumin and MS13 at different concentrations ranging from 1.56 to $100 \mu \mathrm{M}$. Meanwhile, control wells contained untreated cells in appropriate media added with DMSO (0.2\%). Both treated and untreated cells were incubated for $72 \mathrm{~h}$ for dose-dependent cytotoxicity assays and 24, 48, and $72 \mathrm{~h}$ for antiproliferative assay for both dose- and time-dependent. Upon completion, MTT [3-(4,5-dimethylthiazol-2-yl)-2,5diphenyltetrazoliumbromide] assay was performed to determine the cell viability and antiproliferative activity. The media was aspirated and $100 \mu \mathrm{L}$ media with $0.5 \mathrm{mg} / \mathrm{mL}$ MTT solution was added to each wells. The cells then were incubated for $4 \mathrm{~h}$ at $37{ }^{\circ} \mathrm{C}$ in a humidified $5 \% \mathrm{CO}_{2}$ incubator. Following incubation, the excess MTT was discarded and $100 \mu \mathrm{L}$ DMSO was added to each well to dissolve the formazan crystals. The absorbance 
of the blue formazan was read at $570 / 650 \mathrm{~nm}$ wavelength using a microplate spectrophotometer (BioTek ${ }^{\mathrm{TM}}$ EON ${ }^{\mathrm{TM}}$ Microplate Spectrophotometers, Fisher Scientific, Suwanee, GA, USA). The percentage of the cell viability was calculated as follows:

$$
\text { Cell Viability } \%=\frac{\text { Average absorbance of treated cell }}{\text { Average absorbance of untreatedcells }} \times 100
$$

Based on the cell viability percentage, $\mathrm{EC}_{50}$ values were generated using the Graphpad prism version 7 software (Graphpad Software, La Jolla, CA, USA) with nonlinear regression curve fits of the data. The $\mathrm{EC}_{50}$ value indicates the concentration of MS13 required to reduce cell viability by $50 \%$ of the cell population. (R) The overall $\mathrm{EC}_{50}$ of each compound was determined based on the average $\mathrm{EC}_{50}$ values from three independent experiments. Selectivity index (SX) was determined based on the $\mathrm{EC}_{50}$ values obtained from cytotoxicity assays of MS13 against both normal and lung cancer cells. SX values was calculated based on the following equation as previously described $(\mathrm{R})$ :

$$
\text { Selectivity Index }=\frac{\mathrm{EC}_{50}(\text { Normal cell line })}{\mathrm{EC}_{50}(\text { Lung cancer cell lines })} \times 100
$$

SX represents the reference to determine whether a selected compound possesses greater selectivity for achieving therapeutic effects in cancerous cells with minimal toxicity on normal cells (R.F). Selectivity index value above 100 indicates the tested compound possesses a high cytotoxic selectivity towards compared to normal cells [20].

\subsection{Induction of Apoptosis by MS13}

Apoptosis activity of MS13 against lung cancer cells NCI-H520 and NCI-H23 was assessed using morphological evaluation of apoptotic cells, caspase- 3 activity, and bcl-2 cellular protein concentration. The NCI-H520 and NCI-H23 cells were treated with MS13 at approximate concentrations of its respective $\mathrm{EC}_{50}$ [NCI-H520, $5 \mu \mathrm{M}$; NCI-H23, $4 \mu \mathrm{M}$ ] and $2 \mathrm{xEC}_{50}$ [NCI-H520, $10 \mu \mathrm{M}$; NCI-H23, $\left.8 \mu \mathrm{M}\right]$ at 24, 48, and $72 \mathrm{~h}$.

4.4.1. Morphological Evaluation of Apoptotic Cells by Acridine Orange-Propidium Iodide (AO-PI) Double Staining

We used the double staining method using AO-PI to distinguish the morphology of viable, apoptotic, and necrotic cells. Briefly, both of NCI-H520 and NCI-H23 cells were seeded in T25 flasks (Nunc) and grown for $24 \mathrm{~h}$. The test compound (MS13) of various concentrations $\left(\mathrm{EC}_{50}\right.$ and $2 \times \mathrm{EC}_{50}$ ) was added to each flask and incubated at 24,48 , and $72 \mathrm{~h}$ time intervals. Untreated cells containing DMSO alone were used as a negative control. Upon incubation, the cells were pelleted, washed twice in $1 \times$ PBS and resuspended in $150 \mu \mathrm{L} 1 \times$ PBS. Prior to microscopic examination, each sample was mixed with $5 \mu \mathrm{L}$ of acridine orange $(50 \mu \mathrm{g} / \mathrm{mL})$ and $5 \mu \mathrm{L}$ of propidium iodide $(50 \mu \mathrm{g} / \mathrm{mL})$. The cell suspension and dye staining solution mixture was incubated at room temperature in the dark for $5 \mathrm{~min}$. Twenty microliters of the cell suspension and dye mixture was placed on a glass microscopic slide covered with a cover slip. The stained cells were observed and photographed with a fluorescence microscope (BX41, Olympus, Melville, NY, USA) using dual filter set for FITC (green) and rhodomine (red). The experiment was conducted in triplicates. Upon completion, a minimum of 200 cells were counted per sample and the percentage of each cells (viable, apoptotic, and necrotic cells) from each population was calculated based on the following equation [24]:

$$
\text { Percentage of Cells }=\frac{\text { No of viable } / \text { apoptotic } / \text { necrotic cells }}{\text { Total targeted cells }} \times 100
$$

To assess the morphological criteria of viable, apoptotic, and necrotic cells, classification as follows was used [24]:

1. viable cells exhibit uniform green nuclei with intact structure

2. early apoptotic cells exhibit bright-green to yellow nuclei. In addition, characteristics of membrane integrity loss and chromatin condensation 
3. late apoptotic cells exhibit yellow-orange to bright red nuclei as well as condensed or fragmented chromatin,

4. necrotic cells exhibit bright orange or red uniform nuclei.

\subsubsection{Caspase-3 Activity}

Caspase-3 activity of MS13 on NCI-H520 cells was evaluated using the Caspase3 Colorimetric Assay Kit (Raybiotech Inc., Peachtree Corners, GA, USA), following the protocol described by the manufacturer. The assay is based on spectrophotometric detection of $p$-nitroaniline ( $p \mathrm{NA})$, a colored molecule, after its cleavage from the labeled substrate DEVD- $p$ NA by the activity of caspase- 3 enzyme. Briefly, both cells were seeded and grown in T75 flasks (Nunc) until the growth reached $70-75 \%$ confluency. The cells were exposed to MS13 treatment at concentrations of $\mathrm{EC}_{50}$ and $2 \mathrm{X} \mathrm{EC}_{50}$ for 24,48 , and $72 \mathrm{~h}$. Following treatment, cells were washed with PBS and resuspended in $50 \mu \mathrm{L}$ of chilled cell lysis buffer. The mixture of the cells and cell lysis buffer was incubated for $10 \mathrm{~min}$ on ice. After incubation, the cells were spun for $1 \mathrm{~min}$ at $10,000 \mathrm{~g}$. Protein lysate concentrations were measured using bicinchoninic acid (BCA) protein assay kit (Thermo Fisher Scientific, USA) based on the manufacturer's protocol. Upon protein quantification, $200 \mu \mathrm{g}$ of protein lysate was diluted to $50 \mu \mathrm{L}$ of cell lysis buffer for each sample. Next, $50 \mu \mathrm{L}$ of $2 \times$ reaction buffer (containing $10 \mathrm{mM}$ DTT) was added and followed by an additional of $5 \mu \mathrm{L}$ of the $4 \mathrm{mM}$ DEVD-pNA substrate to each assay. The mixture of each assay then was incubated at $37{ }^{\circ} \mathrm{C}$ for $2 \mathrm{~h}$. The intensity of the color was measured at $405 \mathrm{~nm}$ in a microplate spectrophotometer (BioTek ${ }^{\mathrm{TM}}$ EON ${ }^{\mathrm{TM}}$ Microplate Spectrophotometers, Fisher Scientific, USA). Caspase-3 activity was expressed in fold change of absorbance from treated cells against absorbance from untreated cells as shown in following equation:

$$
\text { Fold }- \text { change }=\frac{\text { Absorbance reading }(405 \mathrm{~nm}) \text { of treated cells }}{\text { Absorbance reading }(405 \mathrm{~nm}) \text { of untreated cells }}
$$

\subsubsection{Bcl-2 Cellular Protein Concentration}

Quantification of Bcl-2 cellular protein concentration was performed using the Human Bcl-2 ELISA kit (Invitrogen, Vienna, Austria) following the manufacturing instruction. Prior to the assay, NCI-H520 and NCI-H23 cells were cultured and treated with MS13 (EC50 and $2 \times \mathrm{EC}_{50}$ ) for 24,48 , and $72 \mathrm{~h}$. Then, the total protein was extracted from the treated cells and subjected to the Bcl-2 assay with each well of the supplied microtiter plate has been pre-coated with anti-human Bcl-2 antibody. Briefly, standards as well as samples were added to the wells and followed by Biotin conjugate. The plate then was incubated for $2 \mathrm{~h}$ at room temperature on microplate shaker. After incubation, the wells were washed to remove unbound material. Next, streptavidin-HRP was added to each well and incubated for an hour at room temperature. The wells were washed to remove unbound material and TMB substrate was added which reacted with the HRP enzyme resulting in color development. Last, stop solution was added to terminate color development reaction and the color intensity was measured at a wavelength of $450 \mathrm{~nm}$ by using a microplate spectrophotometer (BioTek ${ }^{\mathrm{TM}}$ EON ${ }^{\mathrm{TM}}$ Microplate Spectrophotometers, Fisher Scientific, USA). The data were presented in a fold-change of absorbance from treated cells against absorbance from untreated cells as shown in following equation:

$$
\text { Fold }- \text { change }=\frac{\text { Absorbance reading }(450 \mathrm{~nm}) \text { of treated cells }}{\text { Absorbance reading }(450 \mathrm{~nm}) \text { of untreated cells }}
$$

\subsection{Gene Expression Analysis}

\subsubsection{Total mRNA Extraction}

Following treatment, the media was removed and washed with 1X PBS for three times. The cells were detached and washed with 1X PBS twice. Next, the cells were resuspended in $1 \mathrm{~mL}$ of $1 \mathrm{X}$ PBS and total mRNA was extracted from the harvested cells using RNeasy Mini Kit (Qiagen, Valencia, CA, USA) according to the manufacturer's protocol. 
Concentration and purity of the extracted RNA was measured using the NanoDrop N60 spectrophotometer (Implen, Westlake Village, CA, USA). High-quality RNA samples with A260/280 ratios ranging from 1.7 to 2.3 and A260/230 ratios ranging from 1.8 to 2.3 were selected for gene expression analysis. The total mRNA content used for gene expression analysis were $75 \mathrm{ng}$. The samples were diluted to the concentration of $15 \mathrm{ng} / \mu \mathrm{L}$ as $5 \mu \mathrm{L}$ of sample was required for gene expression analysis.

\subsubsection{Nanostring nCounter Gene Expression Analysis}

NanoString gene expression profiling was performed on RNA extracted from human lung cancer cells NCI-H520 and NCI-H2 using the nCounter PanCancer Pathways panel (NanoString Technologies, Seattle, WA, USA). The human PanCancer Pathways panel allows the evaluation of 770 genes (730 cancer related human genes, being 124 driver genes and 606 genes from 13 cancer-associated canonical pathways, and 40 as internal reference loci). This panel also contained 6 positive controls with concentrations ranging between $0.125-128 \mathrm{fM}$ and 8 synthetic negative control sequences. Briefly, $75 \mathrm{ng}$ of total RNA isolated from NCI-H520 and NCI-H23 cells were hybridized to specific capture and barcoded panel according to the manufacturer's protocol. The hybridization reaction was incubated at $65{ }^{\circ} \mathrm{C}$ overnight before being immobilized on a cartridge.

\subsubsection{Sample Loading Protocol for nCounter SPRINT $\mathrm{TM}$ Profiler}

Briefly, the NanoString PanCancer cartridge from was equilibrated to room temperature for $15 \mathrm{~min}$. Then, the hybridized samples were removed from the thermocycler and spun down. The RNAse-free water or hybridization buffer was added to sample for final volume of $30 \mu \mathrm{L}$, and $30 \mu \mathrm{L}$ of each sample was loaded into the cartridge. A transparent cover sheet was then sealed over the sample loading ports and the protective green seal was removed from the reagent ports. Finally, the cartridge was placed into the cartridge drawer. Before running the instrument, cartridge was ensured to align in the proper orientation and fully seated in the cartridge tray.

\subsubsection{Data Collection and Data Analysis}

A nCounter Digital Analyzer was used to count the fluorescent barcoded probes to quantify each target RNA molecule. The barcoded images captured by the automated fluorescent microscope were preprocessed for quality control metrics based on field of view (FOV) registration and binding density. Processing and normalization of raw NanoString gene expression data were conducted using the nSolver Advanced Analysis Software (NanoString Technologies $\left.{ }^{\mathrm{TM}}\right)$. Significant entities that demonstrated a $p<0.05$ and differentially expressed genes (DEGs) with fold change greater than or equal to 1.3 (FC $\geq 1.3$ ) and lower than or equal to -1.3 (FC $\leq-1.3$ ) were considered as significant DEGs. Comparisons between the control and the treatment groups for both NCI-H520 and NCI-H23 cells were performed.

\section{Conclusions}

In summary, MS13 demonstrated greater dose-dependent cytotoxicity and dose- and time-dependent antiproliferative activity compared to curcumin in NCI-H520 and NCI-H23 cells. The morphological observation, increase in caspase-3 activity, as well as progressive decrease in Bcl-2 expression indicated induction of apoptosis by MS13. The gene expression analysis revealed that the DEGs modulated by MS13 in NCI-H520 and NCI-H23 cells were highly associated with PI3K, cell cycle-apoptosis, and MAPK signaling pathways. The findings suggest that MS13 may induce antiproliferation and apoptosis activity in squamous cell carcinoma and adenocarcinoma of NSCLC cells by modulating DEGs associated with PI3K-AKT, cell cycle-apoptosis, and MAPK pathways. Therefore, the present study could provide an insight into the anticancer activity of MS13 and merits further investigation as a potential anticancer agent for NSCLC cancer therapy. 
Author Contributions: Conceptualization, W.N.B.W.M.T. and R.N.; methodology, W.N.B.W.M.T.; data collection, W.N.B.W.M.T.; data analysis, W.N.B.W.M.T. and R.N.; resources, I.O. and F.A.; writing-original draft preparation, W.N.B.W.M.T.; writing-review and editing, I.O. and R.N.; project administration, R.N.; funding acquisition, I.O. and R.N. All authors have read and agreed to the published version of the manuscript.

Funding: This research was funded by the Monash Global Asia in the 21st Century (GA21) research grant (GA-HW-19-L03), Monash University Malaysia and Fundamental Research Grant Scheme (FRGS/1/2016/SKK08/MUSM/02/1) under the Ministry of Education (MOE), Malaysia.

Institutional Review Board Statement: Not applicable.

Informed Consent Statement: Not applicable.

Data Availability Statement: The data presented in this study are available within the article.

Acknowledgments: The authors are thankful to Monash University Malaysia for providing financial support to conduct this research.

Conflicts of Interest: The authors declare no conflict of interest.

\section{References}

1. Sung, H.; Ferlay, J.; Siegel, R.L.; Laversanne, M.; Soerjomataram, I.; Jemal, A.; Bray, F. Global cancer statistics 2020: GLOBOCAN estimates of incidence and mortality worldwide for 36 cancers in 185 countries. CA Cancer J. Clin. 2021, 71, 209-249. [CrossRef]

2. Travis, W.D. Pathology of lung cancer. Clin. Chest Med. 2011, 32, 669-692. [CrossRef]

3. Minna, J.D.; Roth, J.A.; Gazdar, A.F. Focus on lung cancer. Cancer Cell 2002, 1, 49-52. [CrossRef]

4. Miller, K.D.; Siegel, R.L.; Lin, C.C.; Mariotto, A.B.; Kramer, J.L.; Rowland, J.H.; Stein, K.D.; Alteri, R.; Jemal, A. Cancer treatment and survivorship statistics, 2016. CA Cancer J. Clin. 2016, 66, 271-289. [CrossRef]

5. Arriagada, R.; Dunant, A.; Pignon, J.-P.; Bergman, B.; Chabowski, M.; Grunenwald, D.; Kozlowski, M.; Le Péchoux, C.; Pirker, R.; Pinel, M.-I.S.; et al. Long-Term Results of the International Adjuvant Lung Cancer Trial Evaluating Adjuvant Cisplatin-Based Chemotherapy in Resected Lung Cancer. J. Clin. Oncol. 2009, 28, 35-42. [CrossRef]

6. Altaf, M.M.; Ahmad Khan, M.S.; Ahmad, I. Chapter 2-Diversity of Bioactive Compounds and Their Therapeutic Potential. In New Look to Phytomedicine; Ahmad Khan, M.S., Ahmad, I., Chattopadhyay, D., Eds.; Academic Press: Cambridge, MA, USA, 2019; pp. 15-34.

7. Panahi, Y.; Hosseini, M.S.; Khalili, N.; Naimi, E.; Simental-Mendía, L.E.; Majeed, M.; Sahebkar, A. Effects of curcumin on serum cytokine concentrations in subjects with metabolic syndrome: A post-hoc analysis of a randomized controlled trial. Biomed. Pharmacother. 2016, 82, 578-582. [CrossRef]

8. Sahebkar, A.; Serban, M.-C.; Ursoniu, S.; Banach, M. Effect of curcuminoids on oxidative stress: A systematic review and meta-analysis of randomized controlled trials. J. Funct. Foods 2015, 18, 898-909. [CrossRef]

9. Moghadamtousi, S.Z.; Kadir, H.A.; Hassandarvish, P.; Tajik, H.; Abubakar, S.; Zandi, K. A Review on Antibacterial, Antiviral, and Antifungal Activity of Curcumin. BioMed Res. Int. 2014, 2014, 186864.

10. Vallianou, N.G.; Evangelopoulos, A.; Schizas, N.; Kazazis, C. Potential anticancer properties and mechanisms of action of curcumin. Anticancer. Res. 2015, 35, 645-651.

11. Mehta, H.J.; Patel, V.; Sadikot, R.T. Curcumin and lung cancer-A review. Target. Oncol. 2014, 9, 295-310. [CrossRef] [PubMed]

12. Wan Mohd Tajuddin, W.N.B.; Lajis, N.H.; Abas, F.; Othman, I.; Naidu, R. Mechanistic understanding of curcumin's therapeutic effects in lung cancer. Nutrients 2019, 11, 2989. [CrossRef]

13. Anand, P.; Kunnumakkara, A.B.; Newman, R.A.; Aggarwal, B.B. Bioavailability of curcumin: Problems and promises. Mol. Pharm. 2007, 4, 807-818. [CrossRef]

14. Paulraj, F.; Abas, F.; Lajis, N.H.; Othman, I.; Naidu, R. Molecular Pathways Modulated by Curcumin Analogue, Diarylpentanoids in Cancer. Biomolecules 2019, 9, 270. [CrossRef]

15. Cen, L.; Hutzen, B.; Ball, S.; DeAngelis, S.; Chen, C.-L.; Fuchs, J.R.; Li, C.; Li, P.-K.; Lin, J. New structural analogues of curcumin exhibit potent growth suppressive activity in human colorectal carcinoma cells. BMC Cancer 2009, 9, 1-8. [CrossRef]

16. Selvendiran, K.; Ahmed, S.; Dayton, A.; Kuppusamy, M.L.; Tazi, M.; Bratasz, A.; Tong, L.; Rivera, B.K.; Kálai, T.; Hideg, K. Safe and targeted anticancer efficacy of a novel class of antioxidant-conjugated difluorodiarylidenyl piperidones: Differential cytotoxicity in healthy and cancer cells. Free Radic. Biol. Med. 2010, 48, 1228-1235. [CrossRef]

17. Tan, X.; Sidell, N.; Mancini, A.; Huang, R.-P.; Shenming, W.; Horowitz, I.R.; Liotta, D.C.; Taylor, R.N.; Wieser, F. Multiple Anticancer Activities of EF24, a Novel Curcumin Analog, on Human Ovarian Carcinoma Cells. Reprod. Sci. 2010, 17, 931-940. [CrossRef]

18. Liang, G.; Shao, L.; Wang, Y.; Zhao, C.; Chu, Y.; Xiao, J.; Zhao, Y.; Li, X.; Yang, S. Exploration and synthesis of curcumin analogues with improved structural stability both in vitro and in vivo as cytotoxic agents. Bioorganic Med. Chem. 2009, 17, $2623-2631$. [CrossRef] [PubMed] 
19. Citalingam, K.; Abas, F.; Lajis, N.H.; Othman, I.; Naidu, R. Anti-proliferative effect and induction of apoptosis in androgenindependent human prostate cancer cells by 1, 5-bis (2-hydroxyphenyl)-1, 4-pentadiene-3-one. Molecules 2015, 20, 3406-3430. [CrossRef] [PubMed]

20. Paulraj, F.; Abas, F.; Lajis, N.H.; Othman, I.; Hassan, S.S.; Naidu, R. The curcumin analogue 1, 5-bis (2-hydroxyphenyl)-1, 4-pentadiene-3-one induces apoptosis and downregulates E6 and E7 oncogene expression in HPV16 and HPV18-infected cervical cancer cells. Molecules 2015, 20, 11830-11860. [CrossRef]

21. Ismail, N.I.; Othman, I.; Abas, F.; Lajis, N.H.; Naidu, R. The Curcumin Analogue, MS13 (1, 5-Bis (4-hydroxy-3-methoxyphenyl)-1, 4-pentadiene-3-one), Inhibits Cell Proliferation and Induces Apoptosis in Primary and Metastatic Human Colon Cancer Cells. Molecules 2020, 25, 3798. [CrossRef]

22. Lee, Y.Q.; Rajadurai, P.; Abas, F.; Othman, I.; Naidu, R. Proteomic Analysis on Anti-Proliferative and Apoptosis Effects of Curcumin Analog, 1, 5-bis (4-Hydroxy-3-Methyoxyphenyl)-1, 4-Pentadiene-3-One-Treated Human Glioblastoma and Neuroblastoma Cells. Front. Mol. Biosci. 2021, 8. [CrossRef]

23. Ng, K.-B.; Bustamam, A.; Sukari, M.A.; Abdelwahab, S.I.; Mohan, S.; Buckle, M.J.C.; Kamalidehghan, B.; Nadzri, N.M.; Anasamy, T.; Hadi, A.H.A. Induction of selective cytotoxicity and apoptosis in human T4-lymphoblastoid cell line (CEMss) by boesenbergin a isolated from boesenbergia rotunda rhizomes involves mitochondrial pathway, activation of caspase 3 and G2/M phase cell cycle arrest. BMC Complement. Altern. Med. 2013, 13, 1-15. [CrossRef]

24. Zimmer, S.; Kahl, P.; Buhl, T.M.; Steiner, S.; Wardelmann, E.; Merkelbach-Bruse, S.; Buettner, R.; Heukamp, L.C. Epidermal growth factor receptor mutations in non-small cell lung cancer influence downstream Akt, MAPK and Stat3 signaling. J. Cancer Res. Clin. Oncol. 2009, 135, 723-730. [CrossRef] [PubMed]

25. Friedman, L.; Lin, L.; Ball, S.; Bekaii-Saab, T.; Fuchs, J.; Li, P.-K.; Li, C.; Lin, J. Curcumin analogues exhibit enhanced growth suppressive activity in human pancreatic cancer cells. Anti-Cancer Drugs 2009, 20, 444. [CrossRef]

26. Yoshida, T.; Maruyama, T.; Miura, M.; Inoue, M.; Fukuda, K.; Shimazu, K.; Taguchi, D.; Kanda, H.; Oshima, M.; Iwabuchi, Y. Dietary intake of pyrolyzed deketene curcumin inhibits gastric carcinogenesis. J. Funct. Foods 2018, 50, 192-200. [CrossRef]

27. Selvendiran, K.; Tong, L.; Bratasz, A.; Kuppusamy, M.L.; Ahmed, S.; Ravi, Y.; Trigg, N.J.; Rivera, B.K.; Kálai, T.; Hideg, K. Anticancer efficacy of a difluorodiarylidenyl piperidone (HO-3867) in human ovarian cancer cells and tumor xenografts. Mol. Cancer Ther. 2010, 9, 1169-1179. [CrossRef]

28. Subramaniam, D.; May, R.; Sureban, S.M.; Lee, K.B.; George, R.; Kuppusamy, P.; Ramanujam, R.P.; Hideg, K.; Dieckgraefe, B.K.; Houchen, C.W. Diphenyl difluoroketone: A curcumin derivative with potent in vivo anticancer activity. Cancer Res. 2008, 68, 1962-1969. [CrossRef]

29. Hutzen, B.; Friedman, L.; Sobo, M.; Lin, L.; Cen, L.; De Angelis, S.; Yamakoshi, H.; Shibata, H.; Iwabuchi, Y.; Lin, J. Curcumin analogue GO-Y030 inhibits STAT3 activity and cell growth in breast and pancreatic carcinomas. Int. J. Oncol. 2009, 35, 867-872. [PubMed]

30. Lin, L.; Liu, Y.; Li, H.; Li, P.; Fuchs, J.; Shibata, H.; Iwabuchi, Y.; Lin, J. Targeting colon cancer stem cells using a new curcumin analogue, GO-Y030. Br. J. Cancer 2011, 105, 212-220. [CrossRef]

31. Lin, L.; Shi, Q.; Nyarko, A.K.; Bastow, K.F.; Wu, C.-C.; Su, C.-Y.; Shih, C.C.-Y.; Lee, K.-H. Antitumor agents. 250. Design and synthesis of new curcumin analogues as potential anti-prostate cancer agents. J. Med. Chem. 2006, 49, 3963-3972. [CrossRef]

32. Van der Goot, H. The chemistry and qualitative structure-activity relationships of curcumin. In Recent Developments in Curcumin Pharmacochemistry; Aditya Media: Mumbai, India, 1997; pp. 13-26.

33. Danial, N.N.; Korsmeyer, S.J. Cell death: Critical control points. Cell 2004, 116, 205-219. [CrossRef]

34. Wong, R.S. Apoptosis in cancer: From pathogenesis to treatment. J. Exp. Clin. Cancer Res. 2011, 30, 1-14. [CrossRef]

35. Porter, A.G.; Jänicke, R.U. Emerging roles of caspase-3 in apoptosis. Cell Death Differ. 1999, 6, 99-104. [CrossRef] [PubMed]

36. Jänicke, R.U.; Sprengart, M.L.; Wati, M.R.; Porter, A.G. Caspase-3 is required for DNA fragmentation and morphological changes associated with apoptosis. J. Biol. Chem. 1998, 273, 9357-9360. [CrossRef]

37. Qu, W.; Xiao, J.; Zhang, H.; Chen, Q.; Wang, Z.; Shi, H.; Gong, L.; Chen, J.; Liu, Y.; Cao, R. B19, a novel monocarbonyl analogue of curcumin, induces human ovarian cancer cell apoptosis via activation of endoplasmic reticulum stress and the autophagy signaling pathway. Int. J. Biol. Sci. 2013, 9, 766. [CrossRef] [PubMed]

38. Cory, S.; Adams, J.M. The Bcl2 family: Regulators of the cellular life-or-death switch. Nat. Rev. Cancer 2002, 2, 647-656. [CrossRef] [PubMed]

39. Kim, M.E.; Ha, T.K.; Yoon, J.H.; Lee, J.S. Myricetin induces cell death of human colon cancer cells via BAX/BCL2-dependent pathway. Anticancer. Res. 2014, 34, 701-706. [PubMed]

40. Faião-Flores, F.; Suarez, J.A.Q.; Soto-Cerrato, V.; Espona-Fiedler, M.; Pérez-Tomás, R.; Maria, D.A. Bcl-2 family proteins and cytoskeleton changes involved in DM-1 cytotoxic effect on melanoma cells. Tumor Biol. 2013, 34, 1235-1243. [CrossRef] [PubMed]

41. Sarris, E.G.; Saif, M.W.; Syrigos, K.N. The Biological Role of PI3K Pathway in Lung Cancer. Pharmaceuticals 2012, 5, 1236-1264. [CrossRef]

42. Papadimitrakopoulou, V. Development of PI3K/AKT/mTOR pathway inhibitors and their application in personalized therapy for non-small-cell lung cancer. J. Thorac. Oncol. 2012, 7, 1315-1326. [CrossRef]

43. Tsurutani, J.; Fukuoka, J.; Tsurutani, H.; Shih, J.H.; Hewitt, S.M.; Travis, W.D.; Jen, J.; Dennis, P.A. Evaluation of two phosphorylation sites improves the prognostic significance of Akt activation in non-small-cell lung cancer tumors. J. Clin. Oncol. 2006, 24, 306-314. [CrossRef] [PubMed] 
44. Tang, J.-M.; He, Q.-Y.; Guo, R.-X.; Chang, X.-J. Phosphorylated Akt overexpression and loss of PTEN expression in non-small cell lung cancer confers poor prognosis. Lung Cancer 2006, 51, 181-191. [CrossRef] [PubMed]

45. Umemura, S.; Mimaki, S.; Makinoshima, H.; Tada, S.; Ishii, G.; Ohmatsu, H.; Niho, S.; Yoh, K.; Matsumoto, S.; Takahashi, A. Therapeutic priority of the $\mathrm{PI} 3 \mathrm{~K} / \mathrm{AKT} / \mathrm{mTOR}$ pathway in small cell lung cancers as revealed by a comprehensive genomic analysis. J. Thorac. Oncol. 2014, 9, 1324-1331. [CrossRef] [PubMed]

46. Sebolt-Leopold, J.S.; Herrera, R. Targeting the mitogen-activated protein kinase cascade to treat cancer. Nat. Rev. Cancer 2004, 4, 937-947. [CrossRef] [PubMed]

47. Labib, K.; Tercero, J.A.; Diffley, J.F.X. Uninterrupted MCM2-7 Function Required for DNA Replication Fork Progression. Science 2000, 288, 1643-1647. [CrossRef] [PubMed]

48. Ren, B.; Yu, G.; Tseng, G.C.; Cieply, K.; Gavel, T.; Nelson, J.; Michalopoulos, G.; Yu, Y.; Luo, J. MCM7 amplification and overexpression are associated with prostate cancer progression. Oncogene 2006, 25, 1090-1098. [CrossRef] [PubMed]

49. Yang, J.-Y.; Li, D.; Zhang, Y.; Guan, B.-X.; Gao, P.; Zhou, X.-C.; Zhou, C.-J. The expression of MCM7 is a useful biomarker in the early diagnostic of gastric cancer. Pathol. Oncol. Res. 2018, 24, 367-372. [CrossRef]

50. Liu, Y.-Z.; Jiang, Y.-Y.; Hao, J.-J.; Lu, S.-S.; Zhang, T.-T.; Shang, L.; Cao, J.; Song, X.; Wang, B.-S.; Cai, Y. Prognostic significance of MCM7 expression in the bronchial brushings of patients with non-small cell lung cancer (NSCLC). Lung Cancer 2012, 77, 176-182. [CrossRef]

51. Fujioka, S.; Shomori, K.; Nishihara, K.; Yamaga, K.; Nosaka, K.; Araki, K.; Haruki, T.; Taniguchi, Y.; Nakamura, H.; Ito, H. Expression of minichromosome maintenance 7 (MCM7) in small lung adenocarcinomas (pT1): Prognostic implication. Lung Cancer 2009, 65, 223-229. [CrossRef]

52. Sreenivasan, S.; Thirumalai, K.; Krishnakumar, S. Expression Profile of Genes Regulated by Curcumin in Y79 Retinoblastoma Cells. Nutr. Cancer 2012, 64, 607-616. [CrossRef]

53. Drechsel, D.; Hyman, A.A.; Cobb, M.H.; Kirschner, M.W. Modulation of the dynamic instability of tubulin assembly by the microtubule-associated protein tau. Mol. Biol. Cell 1992, 3, 1141-1154. [CrossRef]

54. Wang, C.; Liu, Y.; Guo, W.; Zhu, X.; Ahuja, N.; Fu, T. MAPT promoter CpG island hypermethylation is associated with poor prognosis in patients with stage II colorectal cancer. Cancer Manag. Res. 2019, 11, 7337. [CrossRef]

55. Koo, D.-H.; Lee, H.J.; Ahn, J.-H.; Yoon, D.H.; Kim, S.-B.; Gong, G.; Son, B.H.; Ahn, S.H.; Jung, K.H. Tau and PTEN status as predictive markers for response to trastuzumab and paclitaxel in patients with HER2-positive breast cancer. Tumor Biol. 2015, 36, 5865-5871. [CrossRef] [PubMed]

56. Mimori, K.; Sadanaga, N.; Yoshikawa, Y.; Ishikawa, K.; Hashimoto, M.; Tanaka, F.; Sasaki, A.; Inoue, H.; Sugimachi, K.; Mori, M. Reduced tau expression in gastric cancer can identify candidates for successful Paclitaxel treatment. Br. J. Cancer 2006, 94, 1894-1897. [CrossRef] [PubMed]

57. Sekino, Y.; Han, X.; Babasaki, T.; Goto, K.; Inoue, S.; Hayashi, T.; Teishima, J.; Shiota, M.; Takeshima, Y.; Yasui, W. MicrotubuleAssociated Protein Tau (MAPT) Promotes Bicalutamide Resistance and Is Associated with Survival in Prostate Cancer; Urologic Oncology: Seminars and Original Investigations; Elsevier: Amsterdam, The Netherlands, 2020; p. 795.

58. Massague, J. The Transforming Growth Factor-beta Family. Annu. Rev. Cell Biol. 1990, 6, 597-641. [CrossRef] [PubMed]

59. Liao, H.; Liang, Y.; Kang, L.; Xiao, Y.; Yu, T.; Wan, R. miR-454-3p inhibits non-small cell lung cancer cell proliferation and metastasis by targeting TGFB2. Oncol. Rep. 2021, 45, 67. [CrossRef] [PubMed]

60. Dumont, N.; Arteaga, C.L. Transforming growth factor-beta and breast cancer: Tumor promoting effects of transforming growth factor- $\beta$. Breast Cancer Res. 2000, 2, 125. [CrossRef]

61. Lu, R.; Ji, Z.; Li, X.; Qin, J.; Cui, G.; Chen, J.; Zhai, Q.; Zhao, C.; Zhang, W.; Yu, Z. Tumor suppressive microRNA-200a inhibits renal cell carcinoma development by directly targeting TGFB2. Tumor Biol. 2015, 36, 6691-6700. [CrossRef]

62. Adams, J.C. Thrombospondin-1. Int. J. Biochem. Cell Biol. 1997, 29, 861-865. [CrossRef]

63. Byrne, G.J.; Hayden, K.E.; McDowell, G.; Lang, H.; Kirwan, C.C.; Tetlow, L.; Kumar, S.; Bundred, N.J. Angiogenic characteristics of circulating and tumoural thrombospondin-1 in breast cancer. Int. J. Oncol. 2007, 31, 1127-1132.

64. Albo, D.; Rothman, V.L.; Roberts, D.D.; Tuszynski, G.P. Tumour cell thrombospondin-1 regulates tumour cell adhesion and invasion through the urokinase plasminogen activator receptor. Br. J. Cancer 2000, 83, 298-306. [CrossRef]

65. Zhang, J.; Dong, M.; Li, L.; Fan, Y.; Pathre, P.; Dong, J.; Lou, D.; Wells, J.M.; Olivares-Villagómez, D.; Van Kaer, L.; et al. Endonuclease $\mathrm{G}$ is required for early embryogenesis and normal apoptosis in mice. Proc. Natl. Acad. Sci. USA 2003, $100,15782$. [CrossRef] [PubMed]

66. Basnakian, A.G.; Apostolov, E.O.; Yin, X.; Abiri, S.O.; Stewart, A.G.; Singh, A.B.; Shah, S.V. Endonuclease G promotes cell death of non-invasive human breast cancer cells. Exp. Cell Res. 2006, 312, 4139-4149. [CrossRef] [PubMed]

67. Wang, X.; Tryndyak, V.; Apostolov, E.O.; Yin, X.; Shah, S.V.; Pogribny, I.P.; Basnakian, A.G. Sensitivity of human prostate cancer cells to chemotherapeutic drugs depends on EndoG expression regulated by promoter methylation. Cancer Lett. 2008, 270, 132-143. [CrossRef]

68. Dutto, I.; Tillhon, M.; Cazzalini, O.; Stivala, L.A.; Prosperi, E. Biology of the cell cycle inhibitor p21CDKN1A: Molecular mechanisms and relevance in chemical toxicology. Arch. Toxicol. 2015, 89, 155-178. [CrossRef] [PubMed]

69. Mitsuuchi, Y.; Johnson, S.W.; Selvakumaran, M.; Williams, S.J.; Hamilton, T.C.; Testa, J.R. The Phosphatidylinositol 3-Kinase/AKT Signal Transduction Pathway Plays a Critical Role in the Expression of p21WAF1/CIP1/SDI1 Induced by Cisplatin and Paclitaxel. Cancer Res. 2000, 60, 5390. [PubMed] 
70. Abbas, T.; Dutta, A. p21 in cancer: Intricate networks and multiple activities. Nat. Rev. Cancer 2009, 9, 400-414. [CrossRef]

71. Löhr, K.; Möritz, C.; Contente, A.; Dobbelstein, M. p21/CDKN1A mediates negative regulation of transcription by p53. J. Biol. Chem. 2003, 278, 32507-32516. [CrossRef]

72. Fukazawa, T.; Guo, M.; Ishida, N.; Yamatsuji, T.; Takaoka, M.; Yokota, E.; Haisa, M.; Miyake, N.; Ikeda, T.; Okui, T. SOX2 suppresses CDKN1A to sustain growth of lung squamous cell carcinoma. Sci. Rep. 2016, 6, 20113. [CrossRef]

73. Liu, J.; Hu, Y.; Hu, W.; Xie, X.; Ela Bella, A.; Fu, J.; Rao, D. Expression and prognostic relevance of p21WAF1 in stage III esophageal squamous cell carcinoma. Dis. Esophagus 2012, 25, 67-71. [CrossRef]

74. Wei, C.-Y.; Tan, Q.-X.; Zhu, X.; Qin, Q.-H.; Zhu, F.-B.; Mo, Q.-G.; Yang, W.-P. Expression of CDKN1A/p21 and TGFBR2 in breast cancer and their prognostic significance. Int. J. Clin. Exp. Pathol. 2015, 8, 14619-14629. [PubMed]

75. Kuang, Y.-F.; Chen, Y.-H. Induction of apoptosis in a non-small cell human lung cancer cell line by isothiocyanates is associated with P53 and P21. Food Chem. Toxicol. 2004, 42, 1711-1718. [CrossRef] [PubMed]

76. Zhou, Y.; Ho, W.S. Combination of liquiritin, isoliquiritin and isoliquirigenin induce apoptotic cell death through upregulating p53 and p21 in the A549 non-small cell lung cancer cells. Oncol. Rep. 2014, 31, 298-304. [CrossRef] [PubMed]

77. Zeng, Y.; Shen, Z.; Gu, W.; Wu, M. Inhibition of hepatocellular carcinoma tumorigenesis by curcumin may be associated with CDKN1A and CTGF. Gene 2018, 651, 183-193. [CrossRef] [PubMed]

78. Tamura, R.E.; de Vasconcellos, J.F.; Sarkar, D.; Libermann, T.A.; Fisher, P.B.; Zerbini, L.F. GADD45 Proteins: Central Players in Tumorigenesis. Curr. Mol. Med. 2012, 12, 634-651. [CrossRef]

79. Ying, J.; Srivastava, G.; Hsieh, W.-S.; Gao, Z.; Murray, P.; Liao, S.-K.; Ambinder, R.; Tao, Q. The Stress-Responsive Gene GADD45G Is a Functional Tumor Suppressor, with Its Response to Environmental Stresses Frequently Disrupted Epigenetically in Multiple Tumors. Clin. Cancer Res. 2005, 11, 6442. [CrossRef] [PubMed]

80. Zhang, W.; Li, T.; Shao, Y.; Zhang, C.; Wu, Q.; Yang, H.; Zhang, J.; Guan, M.; Yu, B.; Wan, J. Semi-quantitative detection of GADD45-gamma methylation levels in gastric, colorectal and pancreatic cancers using methylation-sensitive high-resolution melting analysis. J. Cancer Res. Clin. Oncol. 2010, 136, 1267-1273. [CrossRef] [PubMed]

81. Guo, W.; Zhu, T.; Dong, Z.; Cui, L.; Zhang, M.; Kuang, G. Decreased expression and aberrant methylation of Gadd45G is associated with tumor progression and poor prognosis in esophageal squamous cell carcinoma. Clin. Exp. Metastasis 2012, 30, 977-992. [CrossRef]

82. Yang, P.; Yuan, W.; He, J.; Wang, J.; Yu, L.; Jin, X.; Hu, Y.; Liao, M.; Chen, Z.; Zhang, Y. Overexpression of EphA2, MMP-9, and MVD-CD34 in hepatocellular carcinoma: Implications for tumor progression and prognosis. Hepatol. Res. 2009, 39, $1169-1177$. [CrossRef]

83. Yuan, W.; Chen, Z.; Chen, Z.; Wu, S.; Guo, J.; Ge, J.; Yang, P.; Huang, J. Silencing of EphA2 inhibits invasion of human gastric cancer SGC-7901 cells in vitro and in vivo. Neoplasma 2012, 59, 105-113. [CrossRef]

84. Chen, L.-X.; He, Y.-J.; Zhao, S.-Z.; Wu, J.-G.; Wang, J.-T.; Zhu, L.-M.; Lin, T.-T.; Sun, B.-C.; Li, X.-R. Inhibition of tumor growth and vasculogenic mimicry by curcumin through down-regulation of the EphA2/PI3K/MMP pathway in a murine choroidal melanoma model. Cancer Biol. Ther. 2011, 11, 229-235. [CrossRef]

85. Moreno-Layseca, P.; Streuli, C.H. Signalling pathways linking integrins with cell cycle progression. Matrix Biol. 2014, 34, 144-153. [CrossRef] [PubMed]

86. Stewart, R.L.; O'Connor, K.L. Clinical significance of the integrin $\alpha 6 \beta 4$ in human malignancies. Lab. Investig. 2015, 95, 976-986. [CrossRef] [PubMed]

87. Boelens, M.C.; van den Berg, A.; Vogelzang, I.; Wesseling, J.; Postma, D.S.; Timens, W.; Groen, H.J.M. Differential expression and distribution of epithelial adhesion molecules in non-small cell lung cancer and normal bronchus. J. Clin. Pathol. 2007, 60, 608. [CrossRef] [PubMed]

88. Chung, J.; Bachelder, R.E.; Lipscomb, E.A.; Shaw, L.M.; Mercurio, A.M. Integrin $(\alpha 6 \beta 4)$ regulation of eIF-4E activity and VEGF translation: A survival mechanism for carcinoma cells. J. Cell Biol. 2002, 158, 165-174. [CrossRef]

89. Ni, H.; Dydensborg, A.B.; Herring, F.E.; Basora, N.; Gagné, D.; Vachon, P.H.; Beaulieu, J.-F. Upregulation of a functional form of the $\beta 4$ integrin subunit in colorectal cancers correlates with c-Myc expression. Oncogene 2005, 24, 6820-6829. [CrossRef]

90. Nikolopoulos, S.N.; Blaikie, P.; Yoshioka, T.; Guo, W.; Giancotti, F.G. Integrin $\beta 4$ signaling promotes tumor angiogenesis. Cancer Cell 2004, 6, 471-483. [CrossRef] [PubMed]

91. Khoshnoodi, J.; Pedchenko, V.; Hudson, B.G. Mammalian collagen IV. Microsc. Res. Tech. 2008, 71, 357-370. [CrossRef] [PubMed]

92. Burnier, J.V.; Wang, N.; Michel, R.P.; Hassanain, M.; Li, S.; Lu, Y.; Metrakos, P.; Antecka, E.; Burnier, M.N.; Ponton, A.; et al. Type IV collagen-initiated signals provide survival and growth cues required for liver metastasis. Oncogene 2011, 30, 3766-3783. [CrossRef]

93. Xiao, Q.; Jiang, Y.; Liu, Q.; Yue, J.; Liu, C.; Zhao, X.; Qiao, Y.; Ji, H.; Chen, J.; Ge, G. Minor Type IV Collagen $\alpha 5$ Chain Promotes Cancer Progression through Discoidin Domain Receptor-1. PLoS Genet. 2015, 11, e1005249. [CrossRef]

94. Salomonsson, A.; Jönsson, M.; Isaksson, S.; Karlsson, A.; Jönsson, P.; Gaber, A.; Bendahl, P.-O.; Johansson, L.; Brunnström, H.; Jirström, K.; et al. Histological specificity of alterations and expression of KIT and KITLG in non-small cell lung carcinoma. Genes Chromosomes Cancer 2013, 52, 1088-1096. [CrossRef] [PubMed]

95. Vliagoftis, H.; Worobec, A.S.; Metcalfe, D.D. The protooncogene c-kit and c-kit ligand in human disease. J. Allergy Clin. Immunol. 1997, 100, 435-440. [CrossRef] 
96. Krasagakis, K.; Krüger-Krasagakis, S.; Eberle, J.; Tsatsakis, A.; Tosca, A.D.; Stathopoulos, E.N. Co-Expression of KIT Receptor and Its Ligand Stem Cell Factor in Merkel Cell Carcinoma. Dermatology 2009, 218, 37-43. [CrossRef] [PubMed]

97. Reichardt, L.F. Neurotrophin-regulated signalling pathways. Philos. Trans. R. Soc. B Biol. Sci. 2006, 361, 1545-1564. [CrossRef] [PubMed]

98. Truzzi, F.; Marconi, A.; Lotti, R.; Dallaglio, K.; French, L.E.; Hempstead, B.L.; Pincelli, C. Neurotrophins and Their Receptors Stimulate Melanoma Cell Proliferation and Migration. J. Investig. Dermatol. 2008, 128, 2031-2040. [CrossRef] [PubMed]

99. Marchetti, D.; Aucoin, R.; Blust, J.; Murry, B.; Greiter-Wilke, A. p75 neurotrophin receptor functions as a survival receptor in brain-metastatic melanoma cells. J. Cell. Biochem. 2004, 91, 206-215. [CrossRef]

100. Rocha, A.S.; Risberg, B.; Magalhães, J.; Trovisco, V.; de Castro, I.V.; Lazarovici, P.; Soares, P.; Davidson, B.; Sobrinho-Simões, M. The p75 neurotrophin receptor is widely expressed in conventional papillary thyroid carcinoma. Hum. Pathol. 2006, 37, 562-568. [CrossRef] [PubMed]

101. Kettunen, E.; Anttila, S.; Seppänen, J.K.; Karjalainen, A.; Edgren, H.; Lindström, I.; Salovaara, R.; Nissén, A.-M.; Salo, J.; Mattson, K.; et al. Differentially expressed genes in nonsmall cell lung cancer: Expression profiling of cancer-related genes in squamous cell lung cancer. Cancer Genet. Cytogenet. 2004, 149, 98-106. [CrossRef]

102. Yuanlong, H.; Haifeng, J.; Xiaoyin, Z.; Jialin, S.; Jie, L.; Li, Y.; Huahong, X.; Jiugang, S.; Yanglin, P.; Kaichun, W.; et al. The inhibitory effect of $\mathrm{p} 75$ neurotrophin receptor on growth of human hepatocellular carcinoma cells. Cancer Lett. 2008, 268, 110-119. [CrossRef]

103. Khwaja, F.; Tabassum, A.; Allen, J.; Djakiew, D. The p75NTR tumor suppressor induces cell cycle arrest facilitating caspase mediated apoptosis in prostate tumor cells. Biochem. Biophys. Res. Commun. 2006, 341, 1184-1192. [CrossRef]

104. Jin, H.; Pan, Y.; Zhao, L.; Zhai, H.; Li, X.; Sun, L.; He, L.; Chen, Y.; Hong, L.; Du, Y.; et al. p75 Neurotrophin Receptor Suppresses the Proliferation of Human Gastric Cancer Cells. Neoplasia 2007, 9, 471-478. [CrossRef]

105. Tabassum, A.; Khwaja, F.; Djakiew, D. The p75NTR tumor suppressor induces caspase-mediated apoptosis in bladder tumor cells. Int. J. Cancer 2003, 105, 47-52. [CrossRef]

106. Ramsay, R.G.; Gonda, T.J. MYB function in normal and cancer cells. Nat. Rev. Cancer 2008, 8, 523-534. [CrossRef] [PubMed]

107. Biroccio, A.; Benassi, B.; D’Agnano, I.; D’Angelo, C.; Buglioni, S.; Mottolese, M.; Ricciotti, A.; Citro, G.; Cosimelli, M.; Ramsay, R.G. $\mathrm{c}-\mathrm{Myb}$ and $\mathrm{Bcl}-\mathrm{x}$ overexpression predicts poor prognosis in colorectal cancer: Clinical and experimental findings. Am. J. Pathol. 2001, 158, 1289-1299. [CrossRef]

108. Greco, C.; Alvino, S.; Buglioni, S.; Assisi, D.; Lapenta, R.; Grassi, A.; Stigliano, V.; Mottolese, M.; Casale, V. Activation of c-MYC and c-MYB proto-oncogenes is associated with decreased apoptosis in tumor colon progression. Anticancer Res. 2001, 21, 3185-3192.

109. van de Vijver, M.J.; He, Y.D.; van't Veer, L.J.; Dai, H.; Hart, A.A.M.; Voskuil, D.W.; Schreiber, G.J.; Peterse, J.L.; Roberts, C.; Marton, M.J.; et al. A Gene-Expression Signature as a Predictor of Survival in Breast Cancer. N. Eng. J. Med. 2002, 347, $1999-2009$. [CrossRef]

110. Guérin, M.; Sheng, Z.M.; Andrieu, N.; Riou, G. Strong association between c-myb and oestrogen-receptor expression in human breast cancer. Oncogene 1990, 5, 131-135.

111. Anfossi, G.; Gewirtz, A.M.; Calabretta, B. An oligomer complementary to c-myb-encoded mRNA inhibits proliferation of human myeloid leukemia cell lines. Proc. Natl. Acad. Sci. USA 1989, 86, 3379. [CrossRef]

112. Lutwyche, J.K.; Keough, R.A.; Hughes, T.P.; Gonda, T.J. Mutation screening of the c-MYB negative regulatory domain in acute and chronic myeloid leukaemia. Br. J. Haematol. 2001, 114, 632-634. [CrossRef] [PubMed]

113. Cuenda, A.; Rousseau, S. p38 MAP-Kinases pathway regulation, function and role in human diseases. Biochim. Biophys. Acta Mol. Cell Res. 2007, 1773, 1358-1375. [CrossRef] [PubMed]

114. Liu, J.; Han, L.; Li, B.; Yang, J.; Huen, M.S.Y.; Pan, X.; Tsao, S.W.; Cheung, A.L.M. F-Box Only Protein 31 (FBXO31) Negatively Regulates p38 Mitogen-activated Protein Kinase (MAPK) Signaling by Mediating Lysine 48-linked Ubiquitination and Degradation of Mitogen-activated Protein Kinase Kinase 6 (MKK6). J. Biol. Chem. 2014, 289, 21508-21518. [CrossRef]

115. Lotan, T.L.; Lyon, M.; Huo, D.; Taxy, J.B.; Brendler, C.; Foster, B.A.; Stadler, W.; Rinker-Schaeffer, C.W. Up-regulation of MKK4, MKK6 and MKK7 during prostate cancer progression: An important role for SAPK signalling in prostatic neoplasia. J. Pathol. 2007, 212, 386-394. [CrossRef]

116. Parray, A.A.; Baba, R.A.; Bhat, H.F.; Wani, L.; Mokhdomi, T.A.; Mushtaq, U.; Bhat, S.S.; Kirmani, D.; Kuchay, S.; Wani, M.M.; et al. MKK6 is Upregulated in Human Esophageal, Stomach, and Colon Cancers. Cancer Investig. 2014, 32, 416-422. [CrossRef]

117. Lin, S.; Liu, K.; Zhang, Y.; Jiang, M.; Lu, R.; Folts, C.J.; Gao, X.; Noble, M.D.; Zhao, T.; Zhou, Z.; et al. Pharmacological targeting of p38 MAP-Kinase 6 (MAP2K6) inhibits the growth of esophageal adenocarcinoma. Cell. Signal. 2018, 51, 222-232. [CrossRef]

118. Satyal, S.H.; Chen, D.; Fox, S.G.; Kramer, J.M.; Morimoto, R.I. Negative regulation of the heat shock transcriptional response by HSBP1. Genes Dev. 1998, 12, 1962-1974. [CrossRef] [PubMed]

119. Eroglu, B.; Min, J.-N.; Zhang, Y.; Szurek, E.; Moskophidis, D.; Eroglu, A.; Mivechi, N.F. An essential role for heat shock transcription factor binding protein 1 (HSBP1) during early embryonic development. Dev. Biol. 2014, 386, 448-460. [CrossRef] [PubMed]

120. Shen, L.; Zhang, R.; Sun, Y.; Wang, X.; Deng, A.M.; Bi, L. Overexpression of HSBP1 is associated with resistance to radiotherapy in oral squamous epithelial carcinoma. Med. Oncol. 2014, 31, 1-7. [CrossRef] [PubMed] 
121. Phan, N.N.; Wang, C.Y.; Chen, C.F.; Sun, Z.; Lai, M.D.; Lin, Y.C. Voltage-gated calcium channels: Novel targets for cancer therapy. Oncol. Lett. 2017, 14, 2059-2074. [CrossRef] [PubMed]

122. Warnier, M.; Roudbaraki, M.; Derouiche, S.; Delcourt, P.; Bokhobza, A.; Prevarskaya, N.; Mariot, P. CACNA2D2 promotes tumorigenesis by stimulating cell proliferation and angiogenesis. Oncogene 2015, 34, 5383-5394. [CrossRef]

123. da Costa Prando, E.; Cavalli, L.R.; Rainho, C. Evidence of epigenetic regulation of the tumor suppressor gene cluster flanking RASSF1 in breast cancer cell lines. Epigenetics 2011, 6, 1413-1424. [CrossRef]

124. Zhang, Y.; Wang, H.; Wang, J.; Bao, L.; Wang, L.; Huo, J.; Wang, X. Global analysis of chromosome 1 genes among patients with lung adenocarcinoma, squamous carcinoma, large-cell carcinoma, small-cell carcinoma, or non-cancer. Cancer Metastasis Rev. 2015, 34, 249-264. [CrossRef]

125. Natrajan, R.; Little, S.E.; Reis-Filho, J.S.; Hing, L.; Messahel, B.; Grundy, P.E.; Dome, J.S.; Schneider, T.; Vujanic, G.M.; PritchardJones, K.; et al. Amplification and Overexpression of CACNA1E Correlates with Relapse in Favorable Histology Wilms' Tumors. Clin. Cancer Res. 2006, 12, 7284. [CrossRef]

126. Camps, M.; Nichols, A.; Arkinstall, S. Dual specificity phosphatases: A gene family for control of MAP kinase function. FASEB J. 2000, 14, 6-16. [CrossRef]

127. Wu, G.S. Role of mitogen-activated protein kinase phosphatases (MKPs) in cancer. Cancer Metastasis Rev. 2007, 26, 579-585. [CrossRef] [PubMed]

128. Keyse, S.M. Dual-specificity MAP kinase phosphatases (MKPs) and cancer. Cancer Metastasis Rev. 2008, 27, 253-261. [CrossRef] [PubMed]

129. Ratsada, P.; Hijiya, N.; Hidano, S.; Tsukamoto, Y.; Nakada, C.; Uchida, T.; Kobayashi, T.; Moriyama, M. DUSP4 is involved in the enhanced proliferation and survival of DUSP4-overexpressing cancer cells. Biochem. Biophys. Res. Commun. 2020, 528, 586-593. [CrossRef]

130. Li, W.; Song, L.; Ritchie, A.-M.; Melton, D.W. Increased levels of DUSP6 phosphatase stimulate tumourigenesis in a molecularly distinct melanoma subtype. Pigment Cell Melanoma Res. 2012, 25, 188-199. [CrossRef]

131. Bell, L.A.; Ryan, K.M. Life and death decisions by E2F-1. Cell Death Differ. 2004, 11, 137-142. [CrossRef] [PubMed]

132. Gorgoulis, V.G.; Zacharatos, P.; Mariatos, G.; Kotsinas, A.; Bouda, M.; Kletsas, D.; Asimacopoulos, P.J.; Agnantis, N.; Kittas, C.; Papavassiliou, A.G. Transcription factor E2F-1 acts as a growth-promoting factor and is associated with adverse prognosis in non-small cell lung carcinomas. J. Pathol. 2002, 198, 142-156. [CrossRef]

133. Eymin, B.; Gazzeri, S.; Brambilla, C.; Brambilla, E. Distinct pattern of E2F1 expression in human lung tumours: E2F1 is upregulated in small cell lung carcinoma. Oncogene 2001, 20, 1678-1687. [CrossRef]

134. Zhang, S.Y.; Liu, S.C.; Al-Saleem, L.F.; Holloran, D.; Babb, J.; Guo, X.; Klein-Szanto, A.J.P. E2F-1: A Proliferative Marker of Breast Neoplasia. Cancer Epidemiol. Biomark. Prev. 2000, 9, 395.

135. Saiz, A.D.; Olvera, M.; Rezk, S.; Florentine, B.A.; McCourty, A.; Brynes, R.K. Immunohistochemical expression of cyclin D1, E2F-1, and Ki-67 in benign and malignant thyroid lesions. J. Pathol. 2002, 198, 157-162. [CrossRef] [PubMed]

136. Huang, C.L.; Liu, D.; Nakano, J.; Yokomise, H.; Ueno, M.; Kadota, K.; Wada, H. E2F1 Overexpression Correlates with Thymidylate Synthase and Survivin Gene Expressions and Tumor Proliferation in Non-Small-Cell Lung Cancer. Clin. Cancer Res. 2007, 13, 6938. [CrossRef] [PubMed]

137. Coutte, L.; Dreyer, C.; Sablin, M.-P.; Faivre, S.; Raymond, E. PI3K-AKT-mTOR pathway and cancer. Bull. Cancer 2012, 99, 173-180. [CrossRef] [PubMed]

138. García, Z.; Kumar, A.; Marqués, M.; Cortés, I.; Carrera, A.C. Phosphoinositide 3-kinase controls early and late events in mammalian cell division. EMBO J. 2006, 25, 655-661. [CrossRef] [PubMed]

139. Cortés, I.; Sánchez-Ruíz, J.; Zuluaga, S.; Calvanese, V.; Marqués, M.; Hernández, C.; Rivera, T.; Kremer, L.; González-García, A.; Carrera, A.C. p85 $\beta$ phosphoinositide 3-kinase subunit regulates tumor progression. Proc. Natl. Acad. Sci. USA 2012, 109, 11318-11323. [CrossRef] [PubMed]

140. Guo, Y.; Bao, Y.; Ma, M.; Zhang, S.; Zhang, Y.; Yuan, M.; Liu, B.; Yang, Y.; Cui, W.; Ansong, E.; et al. Clinical significance of the correlation between PLCE 1 and PRKCA in esophageal inflammation and esophageal carcinoma. Oncotarget 2017, 8, 33285-33299. [CrossRef]

141. Rosenberg, S.; Simeonova, I.; Bielle, F.; Verreault, M.; Bance, B.; Le Roux, I.; Daniau, M.; Nadaradjane, A.; Gleize, V.; Paris, S.; et al. A recurrent point mutation in PRKCA is a hallmark of chordoid gliomas. Nat. Commun. 2018, 9, 2371-2379. [CrossRef]

142. Arora, S.; Ranade, A.R.; Tran, N.L.; Nasser, S.; Sridhar, S.; Korn, R.L.; Ross, J.T.D.; Dhruv, H.; Foss, K.M.; Sibenaller, Z.; et al. MicroRNA-328 is associated with (non-small) cell lung cancer (NSCLC) brain metastasis and mediates NSCLC migration. Int. J. Cancer 2011, 129, 2621-2631. [CrossRef] [PubMed]

143. Jiang, H.; Fu, Q.; Song, X.; Ge, C.; Li, R.; Li, Z.; Zeng, B.; Li, C.; Wang, Y.; Xue, Y.; et al. HDGF and PRKCA upregulation is associated with a poor prognosis in patients with lung adenocarcinoma. Oncol. Lett. 2019, 18, 4936-4946. [CrossRef]

144. Nakamura, T.; Mizuno, S. The discovery of Hepatocyte Growth Factor (HGF) and its significance for cell biology, life sciences and clinical medicine. Proc. Jpn. Acad. Ser. B 2010, 86, 588-610. [CrossRef] [PubMed]

145. Morishita, R.; Aoki, M.; Hashiya, N.; Yamasaki, K.; Kurinami, H.; Shimizu, S.; Makino, H.; Takesya, Y.; Azuma, J.; Ogihara, T. Therapeutic Angiogenesis using Hepatocyte Growth Factor (HGF). Curr. Gene Ther. 2004, 4, 199-206. [CrossRef]

146. Cipriani, N.A.; Abidoye, O.O.; Vokes, E.; Salgia, R. MET as a target for treatment of chest tumors. Lung Cancer 2009, 63, 169-179. [CrossRef] 
147. Comoglio, P.M.; Boccaccio, C. Scatter factors and invasive growth. Semin. Cancer Biol. 2001, 11, 153-165. [CrossRef] [PubMed]

148. Ma, P.C.; Jagadeeswaran, R.; Jagadeesh, S.; Tretiakova, M.S.; Nallasura, V.; Fox, E.A.; Hansen, M.; Schaefer, E.; Naoki, K.; Lader, A.; et al. Functional Expression and Mutations of c-Met and Its Therapeutic Inhibition with SU11274 and Small Interfering RNA in Non-Small Cell Lung Cancer. Cancer Res. 2005, 65, 1479-1488. [CrossRef] [PubMed]

149. Ma, P.C.; Tretiakova, M.S.; Nallasura, V.; Jagadeeswaran, R.; Husain, A.N.; Salgia, R. Downstream signalling and specific inhibition of c-MET/HGF pathway in small cell lung cancer: Implications for tumour invasion. Br. J. Cancer 2007, 97, 368-377. [CrossRef]

150. Cecchi, F.; Rabe, D.C.; Bottaro, D.P. Targeting the HGF/Met signaling pathway in cancer therapy. Expert Opin. Ther. Targets 2012, 16, 553-572. [CrossRef] [PubMed]

151. Jiao, D.; Wang, J.; Lu, W.; Tang, X.; Chen, J.; Mou, H.; Chen, Q.-Y. Curcumin inhibited HGF-induced EMT and angiogenesis through regulating c-Met dependent PI3K/Akt/mTOR signaling pathways in lung cancer. Mol. Ther. Oncolytics 2016, 3, 16018. [CrossRef]

152. Fischer, H.N.; Stenling, R.; Rubio, C.; Lindblom, A. Colorectal carcinogenesis is associated with stromal expression of COL11A1 and COL5A2. Carcinogenesis 2001, 22, 875-878. [CrossRef]

153. Vargas, A.C.; Reed, A.E.M.; Waddell, N.; Lane, A.; Reid, L.E.; Smart, C.E.; Cocciardi, S.; da Silva, L.; Song, S.; Chenevix-Trench, G.; et al. Gene expression profiling of tumour epithelial and stromal compartments during breast cancer progression. Breast Cancer Res. Treat. 2012, 135, 153-165. [CrossRef]

154. Zeng, X.-T.; Liu, X.-P.; Liu, T.-Z.; Wang, X.-H. The clinical significance of COL5A2 in patients with bladder cancer: A retrospective analysis of bladder cancer gene expression data. Medicine 2018, 97. [CrossRef] [PubMed]

155. Wu, D.; Chen, K.; Bai, Y.; Zhu, X.; Chen, Z.; Wang, C.; Zhao, Y.; Li, M. Screening of diagnostic markers for osteosarcoma. Mol. Med. Rep. 2014, 10, 2415-2420. [CrossRef] [PubMed]

156. Bao, L.; Zhang, Y.; Wang, J.; Wang, H.; Dong, N.; Su, X.; Xu, M.; Wang, X. Variations of chromosome 2 gene expressions among patients with lung cancer or non-cancer. Cell Biol. Toxicol. 2016, 32, 419-435. [CrossRef]

157. Barczyk, M.; Carracedo, S.; Gullberg, D. Integrins. Cell Tissue Res. 2009, 339, 269. [CrossRef] [PubMed]

158. Jiao, Y.; Li, Y.; Liu, S.; Chen, Q.; Liu, Y. ITGA3 serves as a diagnostic and prognostic biomarker for pancreatic cancer. OncoTargets Ther. 2019, 12, 4141. [CrossRef]

159. Tang, X.-R.; Wen, X.; He, Q.-M.; Li, Y.-Q.; Ren, X.-Y.; Yang, X.-J.; Zhang, J.; Wang, Y.-Q.; Ma, J.; Liu, N. MicroRNA-101 inhibits invasion and angiogenesis through targeting ITGA3 and its systemic delivery inhibits lung metastasis in nasopharyngeal carcinoma. Cell Death Dis. 2018, 8, e2566. [CrossRef]

160. Kurozumi, A.; Goto, Y.; Matsushita, R.; Fukumoto, I.; Kato, M.; Nishikawa, R.; Sakamoto, S.; Enokida, H.; Nakagawa, M.; Ichikawa, T. Tumor-suppressive micro RNA-223 inhibits cancer cell migration and invasion by targeting ITGA 3/ITGB 1 signaling in prostate cancer. Cancer Sci. 2016, 107, 84-94. [CrossRef]

161. Sa, K.-D.; Zhang, X.; Li, X.-F.; Gu, Z.-P.; Yang, A.-G.; Zhang, R.; Li, J.-P.; Sun, J.-Y. A miR-124/ITGA3 axis contributes to colorectal cancer metastasis by regulating anoikis susceptibility. Biochem. Biophys. Res. Commun. 2018, 501, 758-764. [CrossRef]

162. Sakaguchi, T.; Yoshino, H.; Yonemori, M.; Miyamoto, K.; Sugita, S.; Matsushita, R.; Itesako, T.; Tatarano, S.; Nakagawa, M.; Enokida, H. Regulation of ITGA3 by the dual-stranded microRNA-199 family as a potential prognostic marker in bladder cancer. Br. J. Cancer 2017, 116, 1077-1087. [CrossRef]

163. Li, H.; Wu, H.; Zhang, H.; Li, Y.; Li, S.; Hou, Q.; Wu, S.; Yang, S.-Y. Identification of curcumin-inhibited extracellular matrix receptors in non-small cell lung cancer A549 cells by RNA sequencing. Tumor Biol. 2017, 39, 1010428317705334. [CrossRef]

164. Smrcka, A.V. Molecular targeting of $\mathrm{G} \alpha$ and $\mathrm{G} \beta \gamma$ subunits: A potential approach for cancer therapeutics. Trends Pharmacol. Sci. 2013, 34, 290-298. [CrossRef]

165. Khan, S.M.; Sleno, R.; Gora, S.; Zylbergold, P.; Laverdure, J.-P.; Labbé, J.-C.; Miller, G.J.; Hébert, T.E. The expanding roles of G $\beta \gamma$ subunits in G protein-coupled receptor signaling and drug action. Pharmacol. Rev. 2013, 65, 545-577. [CrossRef] [PubMed]

166. Tanaka, H.; Kanda, M.; Miwa, T.; Umeda, S.; Sawaki, K.; Tanaka, C.; Kobayashi, D.; Hayashi, M.; Yamada, S.; Nakayama, G.; et al. G-protein subunit gamma-4 expression has potential for detection, prediction and therapeutic targeting in liver metastasis of gastric cancer. Br. J. Cancer 2021, 1-9. [CrossRef]

167. Liang, L.; Zeng, J.-H.; Qin, X.-G.; Chen, J.-Q.; Luo, D.-Z.; Chen, G. Distinguishable prognostic signatures of left-and right-sided colon cancer: A study based on sequencing data. Cell. Physiol. Biochem. 2018, 48, 475-490. [CrossRef] [PubMed]

168. Katoh, M.; Nakagama, H. FGF receptors: Cancer biology and therapeutics. Med. Res. Rev. 2014, 34, 280-300. [CrossRef]

169. Li, L.; Zhang, S.; Wei, L.; Wang, Z.; Ma, W.; Liu, F.; Qian, Y. FGF2 and FGFR2 in patients with idiopathic pulmonary fibrosis and lung cancer. Oncol. Lett. 2018, 16, 2490-2494. [CrossRef] [PubMed]

170. Hosoya, T.; Nakata, A.; Yamasaki, F.; Abas, F.; Shaari, K.; Lajis, N.H.; Morita, H. Curcumin-like diarylpentanoid analogues as melanogenesis inhibitors. J. Nat. Med. 2012, 66, 166-176. [CrossRef] 